\title{
GRA M I A I
}

OF THE

\section{CHOCTAW LANGUAGE,}

\author{
BY THE
}

\section{REV. CYRUS BYINGTON.}

Edited from the original MSS. in the Library of the American Philosophical Society,

\section{BY}

$$
\text { P. G. Brinton, M. P., }
$$

Member of the American Philosophical Society; the Pennsylvania Historical Society; Corresponding Member of the American Ethnological Society, etc.

\section{P H I L A D E L P H I A :}

McCalla \& Stavely, Printers, 237-9 Dock Street.

$$
\text { I } 870 \text {. }
$$




\subsection{7 \\ U. S. National Museum. \\ The Rau Library of Archæology.
No. 723}

Dr. Charles Rau was born in Belgium in 1826. He came to the United States in 1848 , and was engaged as teacher at Belleville, Illinois, and in New York. In 1875 he accepted an invitation from the Smithsonian Institution to prepare an Ethnological Exhibit to be displayed at the Centennial Exhibition, and subsequently was appoinled Curator of the department of Arehæology in the National Museum, which position he held at the time of his death, July 25, 1887 . He bequeathed his Archæological collections and library to the U. S. National Museum. 


\section{G R A M M A E}

OF THE

\section{CHOCTAW LANGUAGE,}

BY THE

\section{REV. CYRUS BYINGTON.}

Edited from the original MSS. in the Library of the American Philosophical Society,

BY

p. G. Brinton, M. p.,

Member of the American Philosophical Society; the Pennsylvania Historical Society; Corresponding Member of the American Ethnological Society, etc.

PHILA DELPH I A :

McCalla \& Stavely, Printers, $237-9$ Dock Street.

1870 . 


$$
\begin{aligned}
& \text { PM } \\
& 872 \\
& \text { B9X } \\
& \text { ANTH }
\end{aligned}
$$

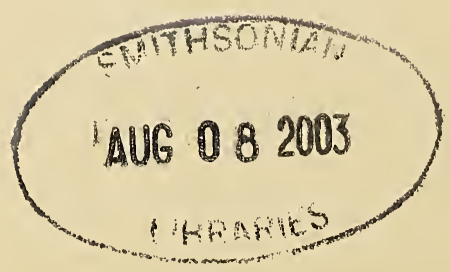




\section{N T RODUC TION.}

The Choctaw, or properly Chahta nation, numbers at present about 17,000 souls, 4,500 of whom are Chickasaws. When first known to Europeans these allied peoples occupied the territory on the left bank of the Mississippi, almost from the Ohio river to the Gulf. They belong to the great CHAнтA-MuskokeE family, which, in early days, controlled the whole country from the Mississippi to the Atlantic, and from the Gulf shore to the Apalachians.

The Choctaws have always been quick to adopt the instruction of their civilized neighbors, and at present have about seventy schools with nearly two thousand pupils on their reservation. ${ }^{1}$ During the French occupation of Louisiana, in the early part of the last century, efforts were made by the Roman Catholic missionaries to convert them, but without success. ${ }^{2}$ In 1818, Protestant missionaries were sent among them, who effected a permanent impression upon them, and were mainly instrumental in bringing about their present highly creditable condition. Their evil habits were reformed, they were instructed in agriculture, and their language was reduced to writing. In the latter, the alphabet suggested by the Hon. John Pickering, in his essay "On a uniform orthography of the languages of the Indians of North America," was employed. The first book printed was a spelling book, by the American Tract Society, in 1825. Since that time, besides a large number of tracts, almanacs, hymn books, and educational works, the whole of the New Testament and most of the Old Testament have been printed in the language, by the American Bible Society, New York city, after faithful translations by the Rev. Cyrus Byington and the Rev. A. Wright, assisted by educated natives. ${ }^{3}$ These can readily be obtained, and will be found of great service in elucidating the grammatical structure of the language, as it is for the first time explained in the present work by the hands of the REV. Cyrus Brington.

This eminent scholar and missionary, whose name is inseparably connected with the later history of the Choctaw nation, was born at Stockbridge, Berkshire county, Massachusetts, March 11, 1793. $\mathrm{He}$

1 Report of the Commissioner of Indian Affairs, for 1869, p. 37.

2 Shea, History of Catholic Missions in the United States, p. 441.

3 In comparing the translation of the Four Gospels, second edition, 1845 (Boston, printed for the A. B. C. F. M.), with the second edition of the New Testament by the American Bible Society (New York, 1854), I find a number of slight differences, especially in the use of the neutral vowel v. 
was one of nine children, and his parents were in humble circumstances, but industrious and respected. His father was at one time a tanner, and subsequently a small farmer. Necessarily, therefore, his early education was limited.

When a well grown lad he was taken into the family of Mr. Joseph Woodbridge, of his native town, from whom he received some instruction in Latin and Greek, and with whom he afterward read law. In 1814 he was admitted to the bar, and practiced a few years with success in Stockbridge and Sheffield, Mass.

His father though a moral was not a religious man, and it seems to have been only after he reached manhood that Mr. Byington became, as he expressed it, "a subject of divine grace." He then resolved to forsake the bar and devote himself to missionary life. With this object in view he entered the theological school at Andover, Mass., where he studied Hebrew and theology, and was licensed to preach, september, 1819. At this time he hoped to go to the Armenians in Turkey. But Providence had prepared for him another and an even more laborious field.

For about a year he preached in various churches in Massachusetts, awaiting some opportunity for missionary labor. Toward the close of the summer of 1819 , a company of twenty or twenty-five persons left Hampshire county, Mass., under the direction of the American Board of Missions, to go by land to the Choctaw nation, then resident in Mississippi. They passed through Stockbridge, in September, and were provided with a letter from the Board, asking Mr. Byington to take charge of them, and pilot them to their destination. He was ready at a few hours' notice.

The company journeyed by land to Pittsburgh, where they procured flat boats, and floated down the Ohio and Mississippi to a point near the mouth of the Yalobusha river, whence a land journey of two hundred miles brought them to their destination.

Thus commenced Mr. Byington's missionary life among the Choctaws. It continued for nearly fifty years, and resulted, with the blessing of Providence and the assistance of some devoted co-workers in the Nation, especially the Rev. A. Wright and the Rev. Cyrus Kingsbury, in redeeming the nation from drunkenness, ignorance and immorality, to sobriety, godliness, and civilization. There are no lives which in the eyes of the philanthropist are more worthy of admiration, or more deserving of record than those of such men, who not only rescue thousands of individuals from spiritual and physical degradation, but preserve with enlightened care the only memorials of whole nations.

For throughout his missionary life Mr. Byington appreciated the value which a knowledge of the language and traditions of the Choctaws would have to scholars. From his arrival among them, there- 
fore, he devoted assiduous labor to their language with a view to comprehend its extremely difficult construction, and to render it available for the missionary and philological student. The first draft of his Grammar was completed in 1834 . It was written and re-written, until at the time of his death, which occurred at Belprè, Ohio, December 31st, 1868, he was at work upon the seventh revisal. This had proceeded as far as the close of Part I. This much, therefore, of the Grammar is almost precisely as the author left it.

Part II. commencing with the Article-Pronouns, I have arranged from the manuscripts of the fifth and sixth revisals, deposited in the library of the American Philosophical Society at Philadelphia, by the family of the author.

In undertaking this task I have throughout adhered closely to the language and arrangement of the original, even where a different nomenclature and an altered arrangement suggested themselves, as in better accordance with modern philological views. It is, I think, more proper to maintain strict fidelity to the forms chosen by so thorough a Choctaw scholar as the Rev. Mr. Byington, in the explanation of so difficult a tongue, than to run any risk of misrepresenting his views by adopting a more modern phraseology.

Mr. Byington's own views of what he had accomplished deserve recording. In his diary under date March 11, 1864 (his birthday), he writes :

"The last year I revised the Choctaw Grammar, going over the ground twice. The last effort I hope is my best, and will be of use to learners of Choctaw, and to Choctaw scholars in schools, but it needs further revision, and then to be well transcribed. I commit these efforts in my old age to the Lord. I have enjoyed these labours very much. The pleasure of happily resolving difficulties in these studies, and of success in the work, is gratifying, and reviving to the mind."

In 1867 he wrote :

"This work can be much improved hereafter by other hands. It may be compared to the first survey and making of a road in a new country."

In spite of these deficiencies, of which no doubt the author was more distinctly aware than any one else, his Grammar remains one of the most valuable, original, and instructive of any ever written of an American language. It is the result of nigh half a century of concentrated study, and we may well doubt if ever again a person will be found who will combine the time, the opportunities, and the ability to make an equal analysis of the language.

Mr. Byington also prepared a Choctaw dictionary, containing about 15,000 words, which remains in manuscript, in the possession of his family. 



\section{GEAMIMAR}

OF THE

\section{CHOCTAW LANGUAGE.}

In commencing the study of Choctaw, those accustomed only to English and cognate languages will discover many peculiarities. Some of them are as follows :

1. The want of the verb "to be" as a declinable word.

2. The want of personal pronouns in the third persons, singular and plural.

3. The want of a plural form in many nouns, verbs and adjectives.

4. The irregular manner in which the plural is made.

5. The want of a passive voice in some verbs, and its irregular formation.

6. The order of words in a clause or sentence.

7. The use of pre-positive particles, or prefixes.

8. The use of post-positive particles, or suffixes.

9. The use of fragmentary pronouns, simple and compound.

10. The repetition of pronouns.

11. The numerous ground-forms of the verbs, arising from internal changes in the primary root.

12. The negative forms of verbs, adjectives, and fragmentary pronouns.

13. The causative forms of verbs.

14. The internal changes in the causative forms.

15. The uniformity of grammatical forms and structure.

16. The extent to which the rough aspirate $h$ supplies the want of the verb of existence.

17. The difficulties in resolving and translating the article-pronouns. 


\section{PAR'T FIRST. OR'THOGRAPHY.}

\section{$\S 1$. The Alphabet.}

Consonants, vowels, diphthongs, nasals, and aspirates are used.

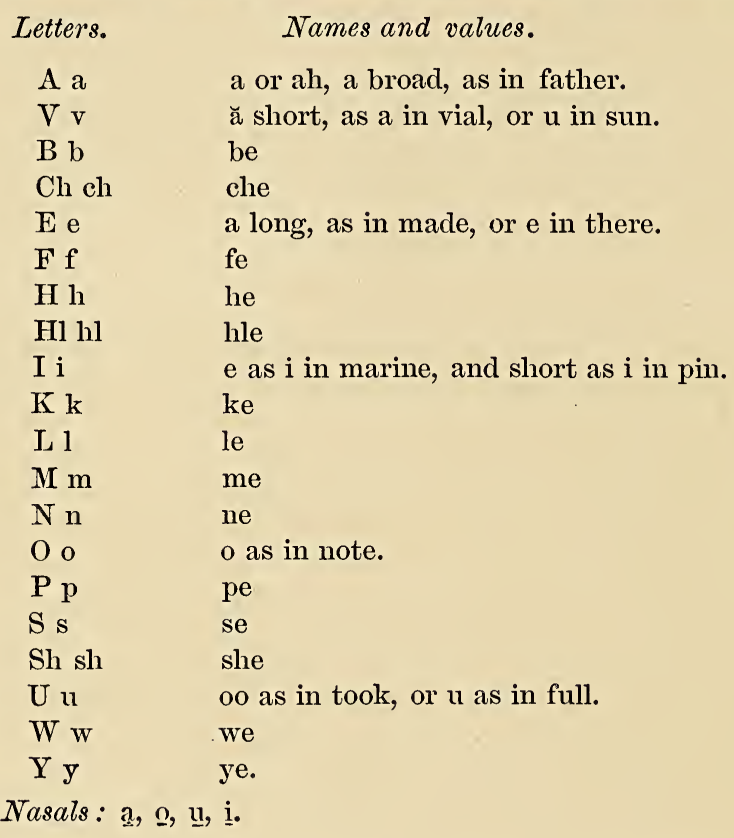

\section{§ 2. Remarks on the Alphabet.}

The vowel $\mathrm{v}$ has heretofore been called $\breve{u}$ short. But the Choctaws give it the sound of $\breve{a}$ short, and when lengthened it passes into $\bar{a}$ long; as, vbi, to kill ; abi, to kill:

$\mathrm{Hl}$, hl, is an aspirated l, when at the beginning of a syllable; when it closes a syllable, it is $\mathrm{lh}$; as, hlibata, a buckskin thong; tulhko, buckskin leather.

$\mathrm{H}, \mathrm{h}$, has two sounds, one a smooth aspirate, as in hina, a road ; the other rough, as in tahli, to finish.

$\mathrm{K}$, $\mathrm{k}$, has two sounds, one sharp, as in oka, water ; the other rough, as in the article-pronoun okvt, oke. In order to express the sound fully, the latter might be spelled okhvt, okhe.

The vowels have the continental sounds.

The diphthongs are: ai, pronounced as $\mathrm{i}$ in pine; and au, as ow in now. 


\section{§3. The Nasals.}

These are not represented by independent letters, but by a line drawn under the vowels, thus : $\mathbf{a}, \underline{i}, \underline{\mathbf{a}} \underline{\mathbf{u}}$, pronounced ang, ing, ong, ung, with slight variations depending upon the next succeeding consonant.

$\mathrm{v}$ nasalized, passes into a.

e " " "

ai " " " " " " ay, as faląiya, to be long, falaya, being long.

au " " " " 6 aw, as lauxa, to be many, lawa, being many.

The nasal sounds increase the distinctive power of the words in which they occur. For instance, the article-pronouns $\mathbf{a}$ definite and $\mathbf{0}$ distinctive are made more definite and distinctive by the nasal mark. This is also true of adverbs of affirmation and negation ; verbs and adverbs take the nasals as intensives ; a, yes it is ; hă, no it is not; keyı, no it is not ; chito, large ; chito, being large, the large one. The nasal sound implies emphasis, and distinctiveness by comparison.

\section{§. Sounds Wanting.}

The consonants c, d, g, j, q, r, v, x, and $\mathrm{z}$, are absent in Choctaw. Double consonants, such as br, dr, tl, bt, nt, st, are of difficult articulation to the natives. When such sounds occur in proper names, as in the Bible, they substitute others, as follows : for c soft they use s, as Cyrus, Sailas; for c hard, k, as Canaan, Kenan; for ch hard, k, as Enoch, Enak; for d, l, as David, Lewi ; or else t, as Daniel, Taniel or Tanili ; for $\mathrm{g}$ soft and for $\mathrm{j}$, ch, as Gentile, Chentail, Jew, Chu ; for g, ko or ku, as queen, kuwin, or kowin ; for $\mathrm{r}, \mathrm{l}$, as Rachel, Lechel, but at the end of a syllable it is dropped, as Peter, Peta ; for $\mathrm{v}, \mathrm{f}$ or $\mathrm{w}$, as Levi, Lefai, David, Lewi ; for $\mathrm{x}$, ks, as Exodus, Eksotus ; for $\mathrm{z}$, s, as Zaccheus, Sakevs. When two consonants come together, a short vowel is sometimes inserted, or one is prefixed: as, wheat, wohet; Andrew, Antilu ; bridle, bilitel; Stephen, Istifin ; Reid, Olit.

\section{$\S 5$. Contractions.}

Contractions by the elision of vowels or consonants are frequent in both simple and compound words and phrases. A few examples are given :

chuka ay ont antah, for onvt antah, he goes to and stays at the house. anont aya, for anolit ayah, he goes along and tells it.

bot vbi, for bolit vbih, he beats and kills.

chukachvfa, for chuka achvfa, a family.

chukfushe, for chukfi ushi, a lamb.

issakshup, for issi hakshup, a deer skin.

siaknip, for sa haknip, my body.

\section{§ 6. Consonant Changes.}

The following change of the consonants may take place : ch may change to sh : ochiah, she draws water; oshtiah, she goes to draw water ; tanchi, corn, tashishi, corn-fodder. Sh may change to $t$, as in the article-pro- 
noun osh, ot. $\mathrm{K}$ and $\mathrm{t}$, and $\mathrm{l}$ and $\mathrm{m}$, are interchangeable in a few words: as ikhana to ithana, to know ; oktvni to ottvni, to appear; omba to oma, to rain ; yukpa changes to yuppa, to be pleased.

\section{§. Vowel Changes.} buy.

$\bar{a}$ shortened becomes $\mathrm{v}$, as chumpa, to buy, chumpvt iah, he goes to

e shortened becomes i, as emah, imah, he gives.

$\bar{o}$ shortened becomes $u$, as tok, tuk, it was, hommah it is red, hummah it is reddish.

$\mathrm{v}$ lengthened becomes a.

ı lengthened becomes e, as pisah, pesah, he sees.

ù lengthened becomes 0 .

$o$ in holissoh becomes $\mathrm{i}$ in hollisichih, he writes.

$a$ in momah becomes $i$ in mominchih.

\section{§ 8. Nasal Changes.}

Exact rules for these changes are not easily given. The nasals $a, i, ~$, $\underline{\mathrm{u}}$, stand before the consonants $\mathrm{f}, \mathrm{h}, \mathrm{hl}, \mathrm{k}, \mathrm{n}, \mathrm{s}, \mathrm{sh}, \mathrm{w}$, and $\mathrm{y}$; as $\underline{\mathrm{i}}$ fuli, his switch ; i hollisso, his book ; $\underline{\mathrm{i}}$ kana, his friend ; wak, his cow ; $\underline{\mathrm{i}}$ yuka, his prisoner. The nasal marks are changed to the letter $\mathrm{m}$ before the diphthongs, the vowels, and the consonants $\mathrm{b}, \mathrm{m}$, and $\mathrm{p}$; and to the letter $\mathrm{n}$ before ch, lh, $\mathrm{l}$, and $\mathrm{t}$; but to these rules there are exceptions; as, imi shilombish, his spirit; i ponaklo, to inquire of him ; nan anoli, an informer ; nan illi, death. The position of the organs of speech preparatory to the utterance of the succeeding letter causes a change in the nasal sound ; as, i wak, his cow ; im issuba, his horse ; in chuka, his house.

\section{§ 9. Doubled Consonants.}

Consonants are doubled in the intensive form of verbs and adjectives ; as,

alota, to be full. anoa, to be reported. vllota, to be quite full. anumpa, to be spoken. himak, now. pila, thither. kvnia, gone. vnnoa, to be commonly reported. vnnumpa, to be much spoken. himmak, hereafter, after all. pilla, away there. kvnnia, really gone.

When the consonant $\mathrm{y}$ is doubled, the first one is transformed into $\mathrm{i}$; as,

hoyo, to look for. ayukpa, to be glad of. ayohmi, to do so there.

hoiya, to look for earnestly. aiyukpa, to be very glad of. aiyohmi, to do so really.

\section{$\$ 10$. Syllabification.}

Syllables usually terminate in a vowel sound, but may end with a consonant. When two simple consonants occur in the same word, the first ends one syllable and the second commences the succeeding one; as, 
bvnna, to want; tohbi, to be white. The double consonants ch, sh, hl, and $\mathrm{lh}$, are inseparable. The long vowels have their full sound in all accented syllables, except the vowel i, which is occasionally short, as in sipsi, a poplar, ilh, to die. In words of two or more syllables the accented syllable takes a consonant, which is heard in both syllables; as, hina, a word, pronounced hinna. In some words the consonant is doubled; as, illi, to die; putta, all. In a few instances the mark ' has been used to indicate emphasis and the imperative mood; as, Luke X. 37, i nukhakklo tok $a^{\prime}$, he that showed mercy on him.

\section{§ 11. ACCEnT.}

In words of two or more syllables the penult is accented; as, kan'chi, to sell; ano'li, to relate. In words of four or more syllables there is a secondary accent on the second syliable before the penult; as, $\mathrm{po}^{\prime} \mathrm{hlomo} / \mathrm{li}$, to double them up; anum'pohon'li, to keep talking. There is another accent which falls on the final syllable of such words as in English are followed by marks of punctuation, from the comma to the period. It is called the pause accent. Consonants take the accent merely, while final vowels take the rough aspirate $h$ suffixed.

\section{$\S 12$. Division of Words.}

All simple words are written separately. There are, however, words compounded with prefixes, suffixes, and inseparable pronouns, which are written as one. But to avoid confusion, whenever it is possible, the elements of each clause are written and printed separately.

\section{§ 13. The Arrangement of Words in a Sentence.}

1. The connective.

2. The subject and its modifications.

3. The object and its modifications.

4. The verb or predicate, with its modifications.

5. Time when comes both before and after the subject.

Time how long is similarly placed, and also at the close of the sentence ; Luke I. 24 ; IV. 25.

6. Instrument and means, with modifications, precede the verb.

7. Adjectives follow nouns.

8. Adverbs follow verbs, adjectives, and adverbs.

9. Infinitives precede the word on which they depend.

10. The place where, comes next after the time when.

11. The imperative follows the noun which is its object; Luke I. 3, 9.

12. The predicate is often at or near the close of the sentence. See Mat. V. 1-12 verses. 


\section{PART SECOND.}

\section{GRAMMATICAL FORMS AND INFLECTIONS.}

\section{Parts of SPeEch.}

There are in Choctaw nine sorts of words, or parts of speech, namely :

1. Article-pronouns, or post-positive particles.

2. Pronouns, or substitutes.

3. Verbs.

4. Prepositions, or pre-positivè particles.

5. Nouns, or names.

6. Adjectives, or attributes.

7. Adverbs, or modifiers.

8. Conjunctions, or connectives.

9. Interjections, or exclamations.

\section{CHAPTER I.}

\section{The Article-Pronouns.}

$\$ 1$. This is the most difficult part of Choctaw Grammar. The want of separate words corresponding to the English articles, of the personal pronouns in the third persons singular and plural, the relative pronouns single and double, and the copulas, is much felt by Americans in studying this language. The article-pronouns are used to supply these wants in a great variety of ways. They do not always admit of a translation. They often merely indicate the case of a word or clause. An accurate and full explanation of them is not attempted. Only a few leading remarks and rules are presented.

$\S 2$. The use of the article-pronouns is for definite and distinctive specification, limitation, emphasis, and prominence, and to show the connection and relation which one word, paragraph, or clause bears to another.

$\S 3$. They are placed after nouns and pronouns with their attributes, after verbs, adverbs, and their attributes, after prepositions and conjunctions. They are definite, distinctive, and contradistinctive, subjective, objective, and copulative. A part of speech can take more than one at a time:

$\S 4$. They may be translated by (1) the articles a, an, the, (2) the adjective pronouns one, ones, some, (3) the personal pronouns he, she, it, they, in the nominative case, and him, her, it, them, in the oblique case, (4) the 
relatives who, which, what, that, in the nominative case, and whom, which, what, that in the oblique case, (5) by the double relatives he who, she who, that which, and they who, (6) and by the one who, the ones who, and the ones whom. Often they are not to be translated in English.

$\S 5$. The primary or ground forms of the article-pronouns are al definite, and distinctive. They are used (1) as articles, (2) as personal pronouns in the third persons singular and plural, (3) as relative pronouns, single and double, in both numbers, (4) as adjective pronouns, (5) as copulas.

\$ 6. a is definite, and when used as an article is much like the English article the, though it is also translated by a, or an. is distinctive, and corresponds to the indefinite $a$ or an in English, or to the adjective pronouns one, ones, some. a implies certain knowledge, while ignores other objects and does not make certain the objects it specifies otherwise than that they belong to one species or kind. o is emphatic. Both are used for specification, emphasis, and case. ${ }^{1}$

$\S 7$. In the oblique case nouns are sometimes found without either of them. And when they are used, they may be rendered by either of the articles, or as mentioned above.

$\S 8$. The article-pronouns have (1) variations, and (2) modifications.

\section{§ 9. a Definite.}

a may be varied by becoming $\mathrm{v}$, e, or $\mathrm{i}$.

It is modified by suffixing various letters, which alter its signification, thus :

It adds $t$, to form the nominative case, at, vt, et, it;

a nasal sound, to form the oblique case, a, i;

$\mathrm{h}$, to form an affirmative (predicate definite), ah, it is the;

$\mathrm{h}$, and varies to e, to form an affirmative (predicate absolute), eh, it is;

$\mathrm{k}$, to form a determinate definite, ak, the, that; and kvt, ket, kit;

sh, to form a renewed mention definite, ash, vsh, the said, the same;

mo, to form a renewed mention distinctive, amo, vmo, the ones.

\footnotetext{
1 Definite and Distinctive. - These two forms of speech run through the whole language, and modity not only article-pronouns, nouns, verbs, and conjunctions, but even clauses and sentences. Mr. Byington explains the double plural of the personal pronoun of the first person, common to nearly all American languages, and generally known as the exclusive plural (excluding the second person) and inclusive plural (including the second person, with or without the third person), the former as definite, the latter as distinctive. These plurals, he says, "correspond to a definite and o distinctive;" and of the separable personal pronouns, vno and sia, he says, "the difference between them is similar to that between a and o." The distinctive expresses in its broadest sense the signification of the word or clause, but lends an emphasis which distinguishes it from any word or clause of allied purport; the definite defines or limits the signification to some specific, known word, individual, or act. Vno, I, distinctive, begins a sentence, the speaker being as yet vague; but as soon as the speaker is defined by a verb, adjective, or other qualifying word, the pronoun changes to sia, I, definite. Vhli, definite, edge, limit, to be the edge or limit of anything, to bound it: this signification is extended in the distinctive form ahli, to be the whole of anything, hence to be true, truth.
} 
It prefixes $m$ in mvt, ma, mak, to express a simultaneous, or concomitant object or act, the too; e. g. Luke XVI. 25, Svso ma! Son! (i.e. thou, too, my son).

\section{$\S 10$. o Distinctive.}

o is modified in a similar manner.

It adds sh, $t$, or cha, to form the nominative, osh, ot, ocha;

a nasal to form the oblique case, $\underline{Q}$, ona;

$\mathrm{h}$, to form an affirmative (predicate distinctive), oh, that is so;

$\mathrm{k}$, to form a determinate distinctive. ok, that one is so;

sh, to form a renewed mention distinctive, osh, the said ones;

mo, to form a renewed mention concomitant, omo, the said ones, too;

$\mathrm{kb}$, to form an optative, okb, oh, that it were so;

$\mathrm{km}$, to form a conditional, okm, if it were so;

keh, to form an affirmative contradistinctive, okeh, it is so and not otherwise;

t, cha, and na, to form connectives.

$\S 11$. The definite and the distinctive are both used separately after one subject, and then the definite follows the noun, and the distinctive its modification. Thus John III. 1, Hatak vt Falisi yosh, a man who was a Pharisee; Luke X. 39, itibapishi hvt Meli hohchifo hosh, a sister whose name was Mary. The distinctive may also be used first, and the definite follow the modification ; Luke XI. 27 , ikfoka yvt yummak osh, the womb that.

$\S 12$. These two article-pronouns and their modifications combine with each other to form the third class, the contradistinctives.

\section{$\S 13$. The Contradistinctives.}

The definite $\mathbf{a}$ in combination with the distinctive :

at, et, vt, take o to form a contradistinctive a, to, eto, uto, nom. case.

a in the oblique case changes to an and takes o, ano, vno.'

ak takes o to make the determinate contradistinctive, ako.

mak takes o to make a simultaneous or successive contradistinctive, mako.

mvt in the nominative case takes o to form a contradistinctive, mvto.

ma in the oblique case becomes man, and takes 0 , mano.

ak becomes ok in ak ok, for intensity of specification.

mak takes ok in mak ok, for the same reason.

a takes mo to form a definite and indeclinable renewed mention in recent past time, as Luke XVI. 13, achvfa kamo, the one. 
The distinctive $\mathbf{O}$ in combination with the definite $\mathbf{a}$ :

ok takes vt in okvt, nom. case, contradistinctive.

ok takes a in oka, oblique case.

ok takes ah in okah, a distinctive and definite predicate.

ok takes eh in okel, a distinctive and absolute predicate.

ok takes ato, vta, in okvta, nom. and okanto.

ok takes ano or vno in okvno, oblique case.

ok takes ak in okak, to double the definitive force of the pronoun.

ok ak takes the pronoun o in okakosh, okako, as a strong definite and concessive, Mark XV. 31.

o takes mo in omo, renewed mention in the remote past tense, indeclinable.

$\S 14$. The following table presents the values and significations of the article-pronouns and their modifying particles, in a brief and comprehensive manner :

a, v, e, i, definite, implying knowledge of the thing, act or individual named; as, wak a, the cow, not a or some coẃ.

$o$, distinctive, generic, implying kind and ignoring other objects, but not rendering the thing, act, or individual certain. It does not specify particular objects, but merely distinguishes them; as, wak o, a cow, not a horse.

ch, connective, and.

$\mathrm{h}$, predicative or affirmative, the sign of existence.

$\mathrm{k}$, determinate or demonstrative, that, the.

kb, optative, wishing it were so, oh that ; definite ; the distinctive form is okb.

$\mathrm{km}$, suppositive, conditional, or contingent, if, when, provided ; definite ; the distinctive form is okm.

$\mathrm{m}$, successive, simultaneous, compellative, when, then, also, too, oh.

mo, renewed mention distinctive, the same, the said; omo, remotely past; amo, recently past.

sh, renewed mention definite of recent past time.

shkeh, definite affirmation, it is.

okeh, distinctive affirmation, it is so and not otherwise.

$\mathrm{t}$, connective, continuative, definite ; a copula, and.

$\mathrm{y}$, euphonic.

$2, \underline{2}, \underline{i}$, nasals, objectives and copulas.

In order that these modifications may be more perfectly understood, some further explanations of the most important of them are added.

$\S 15$. In predicative, or affirmative. The verb of existence, to be, does not occur in Choctaw, and this particle supplies its place. It is suffixed to nouns, pronouns, infinitives, adjectives, adverbs, prepositions, conjunctions, and article-pronouns, which end in a vowel, to form a proposition ; 
when they end in a consonant, the consonant receives an accent called the substantive verb accent. Examples :

vlla, a child.

vno, I.

takchi, to tie.

kvllo, strong.

fehna, very.

anukaka, within.

minti, come.

mihma, and.

a, the.

o, a, one.

he, will, shall.

hatak, man.

chukvsh, heart.

tuk, tok, was, has en. vllah, it is a child.

vnoh, it is I.

takchih, he ties.

kvlloh, he is strong.

fehnah, it is very.

anukakah, it is within.

mintih, it is come.

mihmah, and it is.

$a h$, it is the.

$o h$, it is a, it is one.

heh, it will be, it shall be.

hatak', it is a man.

chukvsh', it is the heart.

tuk $^{\prime}$, tok', it was, it has been.

This particle is not subject to any change for person, number, or gender. Its place is at the end of a proposition. In such expressions as kullo fehnah, he is very strong, the $h$ is removed from kulloh, he is strong, to the end of the sentence. When used with a verb and article-pronoun. it is in printing often prefixed to the latter, instead of being suffixed to the former, where it properly belongs; as, achi hokeh, for achih okeh, he there says.

\$16. I determinate. This particle limits with precision the word to which it is joined,-just that much, no more, no less, and no other. Like $\mathrm{h}$, it is a suffix, although it is often written as a prefix of the following word. Thus, ilvppvt achukma kvt yummak 2 i shahli hokeh, this in goodness is better than that, should be ilvppvt achukmak vt yummak 2 i shahlih oke. The particle $\mathbf{k}$ is also used as a prefix to a vowel in the past and future tenses of verbs in the negative forms, where it has reference to the verb, in order to limit it in this form; as, ik kvllo ke tuk, which should be written, ik kvllok etuk. In renewed mention in remote past time, $\mathrm{k}$ is changed to ch, as chash, chamo, for kash, kamo ; and in some instances $h$ and $k$ are interchangeable, as nachi yim mikvt or nachi yim mihvt, thy faith.

\$17. m successive, simultaneous, compellative. This is a prefix, never a suffix, of a. It may be translated after nouns by, the also, the too; and after verbs by when, then, when then, then when. Examples: iyi máa, the feet too; vmoshi mvto, as for my uncle, he too; aki mvno, as for my father, him also. As a compellative it is prefixed to ah; miko mah, a king. It is prefixed to ak to make a definite expression that something is just now gone before, or will next follow, or is now passing; as, ia lih mak okeh, I am going now.

§18. The form shkeh. The absolute article-pronoun termination shkeh is definite, and follows verbs, adjectives, and adverbs in the present and future tenses, and the pronouns sia, chia, I, thou, etc.

ia lish keh, I go, absolutely, present tense, I am going, I am off.

ia lash keh, I shall go, I will go, let me go, let me off. 
The distinctive form is seen in ia li hok eh, I go instead of doing something else ; ia lish, I go, and $\mathrm{k}$ that, eh, it is ; ia la chi shk eh, go I will and that it is; ia lashke, indefinite and remote future for ia la heshke.

$\S 19$. The conditional forms $\mathbf{m}$ definite, and okm distinctive.

The definite conditional is formed from $\mathrm{k}$ determinate and suffix of a word, and $\mathrm{m}$ a successive and prefix of a, kma. Luke XII. 53; ia lih, I go; ia lik, a determinate act; ia lik ma, when I go then.

The distinctive conditional is made by the pronoun o before $\mathrm{k}$ in $\mathrm{okm}$; ia li hokma, if I go, suppose I go; km and okm take the definite $\mathbf{a}$ with its modifications.

$\S 20$. The optative forms $\mathbf{k b}$ definite and $\mathbf{o k b}$ distinctive. These particles form the optative mood, by prefixing the infinitive of the verb.

$\S 21$. $\mathrm{Y}$ is used as a prefix to an and $\mathbf{o}$. It is euphonic after the vowels $a, i, o$, and before a and o; vlla yvt, vlla yosh, ushi yvt, in place of vlla vt vlla osh, vshi vt.

$\S 22$. The definite article-pronoun of comparison or contrast. This is used to specify objects either as inferior or superior to others when placed in contrast, corresponding to the phrases "how much more," "how much less," especially with definite and pointed emphasis. The simple form is het in the nominative, and hi in the oblique oase. But these are not in use. The compound forms only are used.

Nom. case, ak het, mak het, okak het.

Oblique case, ak hị, mak hị, okak hị.

Contradistinctive form.

Nom. case, ak heto, mak heto, okak heto.

Oblique case, ak heno, mak heno, okak heno.

Conditional form.

Nom. case, $\mathrm{k}$ mak het

ok mak het

Oblique case, $\mathrm{k}$ mak hi

k mak heto

ok mak hi

ok mak heto.

$\mathrm{k}$ mak heno

ok mak heno.

Examples of the use of these pronouns where a contrast is expressed may be found in John III. 20, hokakheto, Mat. XXIII. 26, yokakheto, 1 John V. 9, 2 Cor. III. 8, 9, Luke X. 35, John VIII. 4.

\section{§ 23. General Table of Declensions of the Article-Pronouns.}

The definite:

Nom. case, at, vt, et, it.

Oblique case, $\mathbf{q}, \underline{\mathbf{i}}, \mathbf{i}$.

The distinctive:

Nom. case, osh, ot, ocha.

Oblique case, $o$, 2 , ona.

The contradistinctive:

Nom. case, ato, vto, eto, heto, anto, atoha.

Oblique case, ano, vno, eno, heno, ano, anoha. 
Or in one table:

Nom. case, at, vt, et, it, het; osh, ot, ocha; ato, vto, eto, heto; anto, atoha. Oblique case, a, a, i, i, hi; o, ., ona; ano, vno, eno, heno; ano, anoha.

\section{\$24. Translation of the Article-Pronouns, and their Modifications.}

a definite. When a immediately follows a noun it may generally be translated by the article, or else omitted. When any verb is understood in connection with a noun, a should be translated by a relative pronoun; as, Atvm ak osh hatak moma i tikba hatok, Adam he was of all men the first of them he was; Adam the one who of all men was the first. When a modifying word or words follow the noun, the particle comes last; as, miko vt mintih, the king comes; miko a pisah, the king he sees (regem videt); miko chito vt mintih, the great king comes; miko chito a pisah, he sees the great king. The particle follows pronouns and designates their cases, vno vt, I; vno a, me.

§25. - distinctive. When it follows nouns it denotes them as unknown; nvni chaha yo, a mountain; the particular mountain is not known, but it is made a distinctive object, a mountain and not a plain, or other place. The difference between $\mathbf{a}$ and may be seen in Mat. XVII. 1, and 9, nvnih chaha yo, a mountain; nvnih chaha ya, the mountain. It has an emphatic and prominent meaning in such sentences as Gal. IV. 2, Pal sia hosh, I, Paul; Acts VIII. 20, Chihowa yosh nan ima ya, the gift of God; Acts V. 4, hatak 2 , men. Like a, it is rendered by the personal pronouns in both cases and numbers, he, she, it, they, him, her, it, them, and by the relative and double pronouns. It has a contradistinctive sense in such expressions as Mat. XXV. 3, bila yano, as for the oil, in distinction from the lamps. It is used after verbs, and with some conjunctions, to render a distinct reason for an action; as, Luke XI. 37, ont chukowa cha, impa chi hosh binili tok, he came in and sat down for to eat. It has a concessive sense when combined with the particles ok ak; as, yohmi hokak 0 , although it is so.

Sometimes the article-pronouns are used to translate the articles a and the, and sometimes they are used in Choctaw where the articles do not occur in English. Some examples from Mark I. will illustrate this. The beginning, vmmonak vt; the gospel, vbanumpa; the son of Jehovah, Chihowa ushi; the way, ataya ya; the river of Jordan, Chatan okhina yako; John, Chanvt; Jordan, Chatan ako; Jesus, Chisvs vt; a girdle, vskofvchi yo; water, oka yo; the water, oka ya ; a voice, anumpa hvt; the angels, enchel vhleha hosh; the sea, ok hota; the ship, peni ash; fishers of men, hatak hokli yQ; the unclean spirit, shilombish okpulo ash osh; the unclean spirits, shilombish okpulo hak.

Matth. XV. 38: Mihma okla impa tuk vt, ohoyo vlla aiena hokvto 2sha ho, hatak 4000 ushta tok; And they that did eat were 4000 men, beside women and children. Here vt makes those who ate definite, while ho makes the women and children distinctive and objective. 
Acts IX. 6. nanta hak $Q$ katiohmi la hi a? What wilt thou have me do? is definite; but, Acts XXII. 10: nanta kn katiohmi la chi ho? is distinctive.

\section{§ 26. Table of Translations of the Article-Pronouns.}

1. Nominative case, as articles;

1. Definite, at vt, et, it, a, the.

2. Distinctive, osh, ot, ocha, a, an, the one.

2. Nom. case, as personal pronouns;

1. Definite, at, vt, et, it, he, she, it, they.

2. Distinctive, osh, ot, ocha, he, she, it, they.

3. Nom. case, as relative pronouns;

Definite, at, vt, et, it, who, which, what, that.

4. Nom. case, as double pronouns;

1. Definite, at, vt, et, it, he who, she who, that which, they whos

2. Distinctive, osh, ot, ocha, the one who, some who, the ones who, any one, some one, some who.

5. Renewed mention;

1. Definite, ash, the, the said, the aforesaid.

2. Distinctive, ok, ak, osh, the one, any one who.

6. Contradistinctive;

1. Distinctive, compound, ato, vto, eto, he as for, she as for, it as for, they as for (he as for him, etc).

2. Definite compound, okvto, they which, such as they. See Luke VII. 25, XII. 4.

7. Definite distinctives;

ak osh, he the one who, she the one who, it the one which, they the ones who, they who and not others.

8. Distinctive definite;

ok vt, he, she, it, they particularly.

9. Renewed mention distinctive;

ash, osh, the said he, the said she, the said they. Luke VII, 20, liatak ash ot.

10. Conditional;

1. Definite, kmvt, if the, when the, if he, if she,

2. Distinctive, okmvt, if it were he then, etc

3. Contradistinctive, okmvto, if then as for him, etc,

11. Oblique case, as articles;

1. Definite, a, i, a, an, the.

2. Distinctive, $\stackrel{2}{2}$ ona, a, the, any, some,

12. Oblique case, as personal pronouns;

1. Definite, a, i, him, her, it, them.

2. Distinctive, 2, ona, him, her, it, them.

13. Relative pronouns;

Definite, a, i, whom, which, what. 
14. Double pronouns;

1. Definite, $\underline{a}, \underline{i}$, him whom, her whom, those whom.

2. Distinctive,, , ona, the one whom.

15. Renewed mention;

ash, the said. Luke VII. 19, Chan ash ot.

16. Definite and distinctive;

ok ak $\underline{Q}$, the one whom, any one whom.

17. Contradistinctives;

ano, vno, eno, as for him, her, it, them.

kvno, mvno, okvno.

18. Definite distinctive;

ak 0 , the one whom, he whom, those whom and not others. ak ok, Luke VIII. 12.

aka, him, her, them.

19. Distinctive definite;

20. Renewed mention distinctive;

ash $\varrho$, the said.

21. Conditional;

1. Definite, kma, if him, if her, if it, if them. Luke XII. 53.

2. Distinctive, okma, if so.

1. Definite, kmvno, if him, etc., what then.

2. Distinctive, okmvno, if so what then.

21. Comparative forms;

1. Nom. ak het, particularly he, she, it, you, I, or they.

2. Oblique, ak hi, particularly him, her, it, you, me, or them.

22. Predicative form;

1. Definite, ah, eh, he is, she is, it is, they are.

2. Distinctive, oh.

1. Definite and final, shkeh, it is.

2. Distinctive and final, okeh, it is so and in no other way.

23. Ancient and sonorous forms;

ocha, hocha, yocha.

katoha.

okakanto.

ona, liona, yona.

kanoha.

okakocha.

okakano.

akakona.

These were formerly used by the orators at the public assemblies, but are now almost obsolete. ${ }^{1}$

The compound forms often admit of both the articles, the pronouns, and the relatives, in their translation; alam okash, he the one who; nukhaklo vkleha yokvto, the last word being composed of y euphonic, o distinctive, $\mathrm{k}$ demonstrative, a definite (varied to $\mathrm{v}$ ), $\mathrm{t}$ comnective, and $\mathrm{o}$

\footnotetext{
${ }^{1}$ In former times there was a well known solemn style which abounded in sonorous words. One part of a sentence was nicely balanced by another, and in delivery a chanting or metrical intonation was used. At the close of each paragraph the orator would invite the people to listen, who would in turn indicate approval by crying out yvmmah! It is that! (or "that's so"); and vlphesa! It is right! The most frequent peculiarity of the style was the lengthened pronominal suffixes, as for instance, Nanta hocha? What is it? Nana hona, something. (Byington MSS).
} 
final, and is in form a contra-distinctive, "the merciful, they who are so, as for them, they."

$\S 27$. Position of the article-pronouns. The article and personal pronouns generally follow nouns and their attributes. The relatives follow pronouns, verbs and their attributes; vno vt, I who, ia li tuk vt, I who went I, Svso ilvppvt illi tuk osh, falamvt okchaya hoke, Luke XV. 24.

The article-pronouns are moveable, and may be transferred from the logical to the grammatical subject, in order that they may retain their character as suffixes.

In the tenses, the article-pronouns may either precede the particle by which the tense is indicated, as, a tok, etok, itok, achi, or follow it, as, atuk a, a tok a, a chik a, a tuk $\mathbf{\Omega}$, a tok $\mathbf{2}$ (literally, a, he; tok, past tense particle, did; $\varrho$, it; he did it); anta la chi liatuk oke, Luke XIX. 5, I must abide; hlvpi sabvnnah a tuk, salt I wanted it was, it was salt that I wanted, $\mathrm{h}$ predicative, a a relative pronoun.

$\S 28$. Change of case. A peculiarity in the use of the article-pronoun with nouns is that the nominative case changes to the oblique case when another subject is introduced. For example, Matthew XIII. 4, Atuk osh hokchi ma na nihi kanimi kvt hina lapalika yo kaha tok; atuk o hushi puta kvt ant vpvt tahli tok. Here osh, nom. he (the sower), is changed to ma, oblique, before na nihi kanimi kvt, another subject (some of the seed); and this latter nominative becomes atuk $\mathrm{a}$, oblique, before the next subject, hushi puta kvt, (the fowls).

\section{$\S 29$. Use of the Article-Pronoun with Nouns.}

In connection with nouns, the article-pronouns indicate case, and may thus be regarded as forming a sort of declension. For example:

hatak, man, men.

Nom. case.

hatak okvt, the man, as a man. hatak okvto, the man, as for the man. hatak okmvto, when the men they. hatak ash osh, men the said.
Oblique case.

hatak amo, the said, the same man. hatak oka, as a man, a man. hatak okvno, the men they. hatak okmvno, if men then.

peni vt, the boat, a boat. peni, a boat, boats.

peni $o$, a boat, some boat.

peni mvt, the boat also, a boat too, or also.

peni vto, peni anto, as for the boat, contradistinctive.

peni mvto, as for the boat, also, then.

peni amo, the said boat.

peni osh, a boat, one boat, the boats, some boats.

peni a tuk, peni ya tok, the boat which was.

peni a chi, the boat which will be.

peni a hinla, the boat which can be.

Example: Luke XVII. 32, Lat tekchi a tok a hvsh ithaiyanashke, she who was the wife of Lot, her remember. 


\section{§ 30. Tabular List of Article-Pronouns. ${ }^{1}$}

\begin{tabular}{lr|lr}
\multicolumn{2}{r|}{ Definite forms. } & \multicolumn{2}{c}{ Distinctive forms. } \\
Subjective. & Objective. & Subjective. & Objective. \\
at, vt, et, it, ish & $\underline{a}, \underline{i}$ & osh & o \\
vto, ato & ano, vno & okvt & oka \\
mvt & ma & okmvt & okma \\
mvto & mvno & okbat & okbeh \\
& ak, mak, & okbato & okbano \\
kmvt & kma & omo & omo \\
kmvto & kmak & & \\
kbat & kba & & \\
cha & na & & \\
amo & amo & & \\
lish & li & &
\end{tabular}

Neither subjective nor objective.

\begin{tabular}{r|l} 
h & ok \\
eh & ok ak \\
akok & okm \\
mak & okmak \\
km & okvmo, okamo \\
& ochosh.
\end{tabular}

Finals, or verb substantive forms.

\begin{tabular}{r|l}
$\begin{array}{r}\text { h, eh, } \\
\text { shkeh } \\
\text { ah }\end{array}$ & $\begin{array}{l}\text { hokeh } \\
\text { oh }\end{array}$
\end{tabular}

\section{CHAPTER II.}

\section{Pronouns.}

$\S 1$. The pronouns are divided into two classes, separable and inseparable. Separable pronouns are independent words. Inseparable pronouns are fragmentary words, and are all prefixed to other words, except li, I, which is suffixed.

\section{Separable Pronouns.}

$\S 2$. These are of four classes, 1 , distinctive personal; 2 , definite personal; 3 , possessive; 4, personal-and-possessive.

\footnotetext{
1 Subjective and Objective.-These expressions are used by Mr. Byington rather in their logical than their grammatical sense, and must be so understood in this Table. The llst here given is evidently not complete, but it is accurately copied from his latest revision.
} 
1. The distinctive, or emphatic personal.

\section{Simple form.}

vno, I, me, mine.

chishno, thou, thee, thine.

pishno, we, us, our (def).

hvppishno, we, us, our (dis).

hvchishno, you, yours.
With h predicative.

vnoh, it is I, it is mine.

chishnoh, it is thou, thine.

pishnoh, it is we, ours.

hvpishnoh, it is we, ours.

hvehishnoh, it is you, yours.

§ 3. These pronouns are used in the nominative, oblique, and possessive cases for all genders, without change of form. Their case is shown by the article-pronouns, which they take for specification, emphasis, and case. They are prominent, generally standing at the beginning of a sentence without an antecedent, and are repeated by the inseparable pronouns which follow in the same clause or sentence. They are nasalized with some of the article-pronouns; as, vno vto, vnonto, as for me; vno ak osh, I the one who, but vnak osh, I being the one who.

Note.-The first person plural has two forms. The first is the definite or exclusive plural, and does not include all who are present, but only a fixed number. The second is the distinctive or inclusive plural, and embraces the speaker and all who are present, but ignores all others. All personal and possessive pronouns have this double plural.

\section{The definite Personal.}

Simple form.

sia, I, ne.

chia, thou, thee.

pia, we, (def.) us.

hrpia, we, (dis.) us.

hvchia, you.
With $\mathrm{h}$ predicative.

siah, I am.

chiah, thou art.

piah, we are.

hvpiah, we are.

hvchiah, you are.

These pronouns generally have an antecedent, either a noun, or the clistinctive personal pronoun, or both. They may be in the nominative or oblique case, which is denoted by the article-pronoun which follows them.

$\S 4$. The personal pronouns in the third person, singular and plural, are wanting. They are supplied by a gesture, or by other pronouns; as, ilvppa, this; yvmma, that; ilap, he, she, it, his, her, its; mill, he, she, it, they, the same, the said; okla, people. When no pronoun is expressed, the third person is understood.

'I have here retained Mr. Byington's definition, but I have no doubt the Choctaw double plural is similar to that of other Anierican tongues. The first plural, definite or exclusive, excludes the second person; the second, distinctive or inclusive plural, includes the second person, and may or may not, include the third person. Thus the Indians in speaking to the whites, would say pishno, we (excluding the hearers), but to those of their own nation, hvpishno (including the hearers). The terms exclusive and inclusive to designate this distinction were, I think, first introduced by Father Holguin, in his Grammatica y Arte Nveva de la Lengva Qquichua (Ciudad de los Reyes, 1607), and he calls attention to the fact that when used with verbs, the distinction refers to the action of the verb: "mas no se toma con verbos, por razon del pronombre, como aqui [where the pronouns are independent], sinu por la significacion del verbo, si es en todos o no ygual, o si se excluyen de la accion del verbo, $o$ de su significacion, aquellos con quien se habla" (fol. 12 recto). In the Grammar of the Dakota Language p. 9, the Rev. Mr. Riggs defines the inclusive as a dual (I and

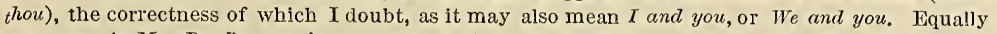
erroneous is Mr. Du Ponceau's comparison of the exclusive plural with nous autres, in French (Langues Sauvages de $l$ Amerique du Nord, p. 155̂), because no us autres does not necessarily exclude the hearers. 
$\S 5$. Examples of the use of the definite and distinctive personal pronouns : Acts X. 26, vno ak kia hatak sia akinli hoke, $I$ am also a man; Mat. XIV. 27, vno ash sia hoke, it is $I$; Luke XVIII. 13, nan ashvchi sia hoka, for I am a sinner; Exodus XX. 2, vno ak osh Chin Chitokaka Chihowah sia hosh Echip yakni a-chi kokchi li tuk oke, I am the Lord thy God which have brought the out of the land of Egypt, vno I distinctive, sia I definite.

6. The possessive.

Simple form.

vmmi, mine.

chimmi, thine.

immi, his, hers.

pimmi, ours (def).

hvpimmi, ours (dis).

hvchimmi, yours.

immi, theirs.

The reciprocal forms of this pronoun are: ittimmi, each other's; ittimmil, they are each other's, singular and plural.

$\S \%$ Personal-and-possessive pronouns.

Simple form.

Definite, ilap, (he, she, it, and ilapa $\{$ his, hers, its, his own, ilapah $\}$ it is his, hers, its, theirs,

Distinctive, ilapo (they, theirs, their own. ilapoh

With h predicative.

vmmih, it is mine. chimmih. it is thine. immih, it is his, hers. pimmih, it is ours. hvpimmih, it is ours. hvchimmih, it is yours. immih, it is theirs.

The first and second persons are formed by prefixing inseparable personal pronouns; thus:

salap, I myself, me myself.

chilap, thou thyself, thee thyself.

pilap, we, us, ourselves (def).

hvpilap, we, us, ourselves (dis).

hvchilap, you yourselves.

And to these again the inseparable possessive pronouns may be suffixed; thus:

Def. ilapi, ilapim, ilapin, his own, her own, their own.

Dis. ilapoi, ilapoim, ilapoin, his own, etc.

Examples: Mark I. 34, ilapa okla ithana hatuk @, because they knew him; Mat. X. 32, vno ak kia ilapa, I also him; John XIII. 3, ilap ak 2 ibbak a, his hands.

$\S 8$. The separable pronouns are the same for all genders, as are also all other pronouns, nouns, and verbs. They take the article-pronouns for the purpose of specification, emplasis and case. They can all take the intensive pronoun inli, self; e. g.: vno inli, I myself too; sia hak inli, ilap ak inli, etc.

\section{Inseparable Pronouns.}

$\S 9$. These are of seven classes, 1 , subjective-personal, 2 , objective-personal, 3, objective-possessive, 4 , reflexive, 5, reciprocal personal, 6 , recip- 
rocral possessive, 7 , the marriage or sacred pronoun. They are always prefixed (except li, I,) to the words with which they are in concord, and are never used alone.

$\S 10$ The subjective-personal.

Affirmative form.

li (a suffix,) I.

ish, is, thou.

e, il, we (def).

eho, iloh, we (dis).

hvsh, hvs, you.
Negative form.

ak, I not.

chik, thou not.

ik, he, she, it not.

ke, kil, we not.

heloh, kiloh, we not.

hvchik, you not.

ik, they not.

$\mathrm{E}$ and eho stand before consonants, il and iloh before vowels. The third persons are wanting in the affirmative form. $\mathrm{Li}$ is the only one of the subjective personals that takes the article-pronouns.

$\S 11$. These pronouns are used in the nominative case with transitive, intransitive, neuter, and passive verbs. When used with neuter and passive verbs they imply an active state, signification, being, or condition. Examples:

Transitive verbs, tackchi, to tie.

takchil, he ties it (h predicative).

takchihlh, I tie it.

ish takchih, thou tiest it.

Intransitive verbs, nowa, to walk.

nowa lih, I walk.

Neuter verbs, nusi, to sleep.

nuse lih, I sleep.

Passive verbs, holitopa, to be honored.

holitopalih, I get honor.

When these pronouns are used with neuter and passive verbs, the subject of the proposition is active.

These pronouns are rendered as possessives by changing the verbs to nouns; as, apehlichi, to rule there; apelichi lih, I rule there; apelichi li, my kingdom; ish apelichi, thy kingdom; it aiashvchi, our sins; itti bapishi li Sal mah, my brother Saul (from itti bapishi, to suck the breast together).

$\S 12$. The objective personal.

Affirmative form.

s, sa, sv, sai, si, I, me, my.

chi, ch, thou, thee, thy. wanting

pi, p, we, us our (def).

hvpi, hvp, we us our (dis).

hvchi, hveh, you, your. wanting
Negative form.

iks, ik sa, ik sv, ik sai, ik so, not me.

ik chi, ik ch, not thee.

ik, not him, not her.

ik pi, ik p, not us.

ik hvpi, ik hvp, not us.

ik hvchi, ik hvch, not you.

ik, not them.

$\$ 13$. These forms are used where by the pronoun no action is implied. They are not in the nominative case, although in common conversation 
they are thus translated. They should be treated as in the oblique case. They are used as subjective, objective, or possessive pronouns, and are prefixed to transitive, passive, and neuter verbs, to those nouns which pertain to one's person, to the various members, and to near family relatives. Examples :

Transitive verbs:

chi pesah, he sees thee.

hvchi hakloh, he hears you.

Passive verbs: chi tallakchih, bound thee it is.

Neuter verbs: chi abekah, thee sick be. chi achukmah, thee good be. sa yonhah, me fever be.

Names of members, and relatives: sa nushkoboh, my head, me head, it is. sa chunkvsh', it is my heart. svsoh, it is my son. satekchih, it is my wife. svpvfv, my dog, it is my family dog. sabaiyih, it is my nepherv. subbitek', it is my niece.

The h predicative, or its accent ', will be observed at the end of these sentences.

$\S 14$. The objective possessive.

Affirmative' form.

a, am, vm, vmi, an, sa, sam, sum, sumi, san, my, of me, to me, for me,

chị, chim, chimi, chin, from me, \&c,

i, im, imi, in, pi, pim, pimi, pin, hvpi, hvpim, hvpimi, hvpin, hvchi, hvchim, hvchimi, hvehin, i, im, imi, in. of thee, etc. of him, her, it, of our (def). of our (dis). of your. of their.

Negative form.

ik sa, iksam, iksvm, ik san, not of me, not to me, not for me. ik chi, ikchim, ikchin, ik i, ik im, ikin, ik pi, ikpim, ikpin, ik hvpi, ikhvpim, ikhvpin, ik hochi, ikhvchim, ikhvchin, ik i, ikim, ikin, not of the, etc. not of him, her, it, etc. not of us. not of us. not of you, not of them.

$\S 15$. This class of pronouns is used where there is an acquisition and possession, but not an implied ownership as a part of the thing spoken of. ${ }^{1}$ Thus; a shapo, my hat (French, chapeau); vmissuba, my horse; an chuka, my house, are things acquired and possessed; but sanushkobo, my head; svbbak, my hand; are integral parts of my person. A few nouns relating to the person take the possessive pronouns; as, vmiskonata foni, my collar-bone; vm uksak foni, my ankle bone.

1 An analogous difference occurs in construction in the Algonkin dialects : "Les étrês qui tiennent leur manière d'être du Créateur, prennent la nıarque du possessif, Les êtres qui tiennent leur manière d'être de l'homme ne le prennent pas." Etudes Philologiques sur quelques Langues Sruvages de l'Amerque, p. 44. 
$\S 16$. These pronouns are prefixed to nouns and verbs, transitive, intransitive, passive, and neuter. Before nouns they may be translated, of him, of her, in the singular, and of them in the plural; as, Chan in chuka, John of him house, John's house ; Chan micha Chemis in chuka, John and James's house, or houses, for them, of them, etc.

Before transitive and intransitive verbs they may be rendered by to, for, from, or of him, of her, of them; as, in chumpah, le buys for or from him, her, or them; i kanchih, he sells to him, or for him, or them; im ia lih, I go for him, imonah, she goes to him; pim vlah, he comes to us, or for us.

Before passive and neuter verbs they may be translated by of him, for him, to him; or, by I, thou, he. Examples:

Passive verbs, intvllakchih, she is bound for him. i boa, it is beaten for him. im patafah, it is plowed for him.

Neuter verbs, $\mathbf{i}$ kulloh, he is hard to him. im achukmah, he, she, it is good to him. im puttah, they are all for him, all his. in tonlah, it lies for him. im ashah, they sit for him. im ahobah, it seems to him.

\section{$\S 17$. The reflexive.}

This is ille, ill, he himself, she herself, etc. It is used where the subject and object are the same. Example:

ille takchi, to tie himself or herself.

Affirmative forms.

ille takchih lih, ish ille takchih, ille takchih, il ille takchilh, iloh ille takchih, hvsh ille takchih, ille takchil,

\section{Negative forms.}

ak ille takchoh, chik ille takchoh, ik ille takchoh, kil ille takchoh, kiloh ille takchoh, hvchik ille takchoh, ik ille takchoh,
I tie myself. thou tiest thyself. he ties himself, she, it, etc. we tie ourselves (def). we tie ourselves (dis). you tie yourselves. they tie themselves.

I do not tie myself. thou dost not tie thyself. he, she, does not tie himself, herself. we do not tie ourselves. you do not tie yourselves. they do not tie themselves.

$\S 18$. The reciprocal-personal.

This is itti, itt; the former before a consonant, the latter before a vowel. They are used where the subject and object both being either in the nom- 
inative or oblique case mutually act on each other; as, itti takchil, to tie each other together. Examples:

itti takchilih, ish itti takchih, itti takchih, il itti takchill, iloh itti takchih, hvsl itti takchih, itti halvllih,
I tie lim together with me.

thou tiest him together with thyself. he, she, it, they tie each other together. we tie each other together, (def). (dis).

you tie each other together. they pull each other.

§ 19. Reciprocal possessive.

This is ittí, ittim, ittin, of, to, for, from each other; as, itti halvlli, they pull from or against each other. Both these and the preceding class, unite with the subjective personal inseparable pronouns.

\section{$\S 20$. The marriage or sacred pronoun.}

This is ho before consonants, ol before vowels. It is used in the first, second, and third persons singular, and the second and third persons plural, as a substitute for son-in-law, father-in-law, mother-in-law, their brothers, sisters, and cousins. It has no variation to express number, case, or gender. It is limited in use to the persons whose relationship is created by marriage; except the husband and wife. It is going out of use, as well as the ancient usages about marriage, especially that which required the mother-in-law and son-in-law to avoid each other. The use of this pronoun may be compared to the emphatic he or she, with which the master or mistress of the house is sometimes referred to in English; as, when he comes back, meaning father, or husband. The father says to his son-in-law, vmissuba ik hopeso, has he not seen my horse? oh ia lih, I went with him; ho mintilih, I come with him, or her; oh ant ik sapeso ka hinlah? will he not come to see me?

$\S 21$. Combinations of the six classes of inseparable pronouns with the verb pisa, or pesa, to see.

1. The subjective and objective personal.

Affirmative form.

clii pesa lih, pisa lih, hvchi pesa lih, pisa lilh, issa pesah, ish pisah, ish pi pesah, ish pisah, sa pesah, chi pesah, pisah, pi pesah, hvchi pesah,
I see thee, I see him, her, or it, I see you, I see them, thou seest me, thou seest him, her, it, thou seest us, thou seest them, he sees me, he sees thee, he sees him, her, it, he sees us, he or she sees thee,
Negative form. ak chi pesoh, ak pesoll, ak hvchi pesol,, ak pesoh, cliik sa pesol, chik pesoh, chik pi pesol,, chik pesoh'; ik sa pesoh, ik chi pesoh, ik pesoh, ik pi pesoh, ik hvchi pesoh, 
Affirmative form.

$\begin{array}{ll}\begin{array}{l}\text { pisah, } \\ \text { e chi pesah, }\end{array} & \text { we or she sees them, } \\ \text { e pisah, } & \text { we see him, her, it, } \\ \text { eho pisah, } & \text { we see ourselves (dis.), } \\ \text { e hvchi pesah, } & \text { we see you, } \\ \text { e hohvchi pisah, } & \text { we (all present) see you, } \\ \text { e pisah, } & \text { we see them, } \\ \text { hvs sa pesah, } & \text { ye see me, } \\ \text { hvsh pisal, } & \text { ye see him, her, it, } \\ \text { hvsh pi pesah, } & \text { ye see us, } \\ \text { hvsh pisah, } & \text { ye see them, } \\ \text { sa pesah, } & \text { they see me, } \\ \text { chi pesah, } & \text { they see thee, } \\ \text { pisah, } & \text { they see him, her, it, } \\ \text { pi pesah, } & \text { they see us, } \\ \text { hvchi pesah, } & \text { they see you, } \\ \text { pisah, } & \text { they see them, }\end{array}$

Negative form.

ik pesoh, ke chi peso, ke pesoh, ke ho pesol, ke hvchi pesoh, ke hohvchi pesoh, ke pesoh, hvchik sa pesol, hvchik pesol, hvchik pi pesoh, hvchik pesol, ik sa pesoh, ik chi pesoh, ik pesoh, ik pi pesoh, ik hvchi pesoh, ik pesoh.

2. Subjective personal and reflexive.

Affirmative.

ille pis alib, ish ille pisah, ille pisah, il ille pisah, eloh ille pisah, hvsh ille pisah, ille pisah,

I see myself, thou seest thyself, he, etc., sees himself, we see ourselves (def.), we see ourselves (dis.), you see yourselves, they see themselves,
Negative.

ak ille pesoh, chik ille pesol, ik ille pesoh, kil ille pesoh, kiloh, ille pesoh, hvck ille pesoh, ik ille pesoh.

Ille occasionally takes a locative and drops e; as, illąhobachi, to make like to himself.

3. Subjective, objective, and reciprocal-personal.

Affirmative.

Negative. chitti pesalih, itti pesa lih, I see thee and thou seest me, I see him and he sees me, hvsh itti pesa lih, I see you and you see me, itti pesa lih, I see them, etc., is svtti pesah, ish itti pesah, ish pitti pesah, ish itti pesah, svtti pesah, chitti pesah, itti pesah, thou seest me and I see thee, thou seest him and he sees thee, thou seest us and we see thee, ak chitti pesoh, ak itti pesol, ak hvchitti pesoh, ak itti pesoh, chik svtti pesoh, chik itti pesoh, thou seest them and they see thee, chik itti pesoh, he sees me and I see him, ik svtti pesoh, he sees thee and thou seest him, ik chitti pesoh, he sees him, her, and she, he, sees

\section{him,}

pitti pesah, hvchitti pesah, itti pesah, he sees us and we see him, he sees you and you see him, he sees them and they see him, ik itti pesoh, ik pitti pesol, ik hvchitti pesol, ik itti pesoh, 
Affirmative.

e chitti pesah, il itti pesah, iloh itti pesah, e hvchitti pesah, il itti pesah, hvs sitti pesah, hvsh itti pesah, hvsh pitti pesah, livsh itti pesah, svtti pesah, chitti pesah, itti pesah, pitti pesah, hvchitti pesah, itti pesah, we see thee and thou seest us, we see him and he sees us, we see one another, we see you and you see us, we see them and they see us, you see me and I see you, you see him and he sees you, you see us and we see you, you see them and they see you, they see me and I see them, they see thee and thou seest they see him and he sees them, ik itti pesoh, they see us and we see them, ik pitti pesoh, they see you and ye see them, hvchik itti pesoh, they see one another, ik itti pesoh.
Negative.

ke chitti pesoh, kil itti pesoh, kiloh itti pesoh, ke hvchitti pesoh, kil itti pesoh, hvchik svtti pesoh, hvchik itti pesoh, hvchik pitti pesoh, hvchik itti pesoh, ik svtti pesoh,

4. The possessive-objective, in combination with the subjective-personal and objective personal.

Affirmative. chị pisa lih, i pisa lih, livchi pisa lih, i pisa lih, is sa pisah, ishị pisah, ish pi pisah, ish $\underline{\mathrm{i}}$ pisah, a pisah, chị pisah, i pisah, pi pisah, hvchi pisah, i pisah, e chi pisah, il i pisah, iloh i pisah, e hvchi pisal,, eho hvchi pisah, il i pisah, hvs sa pisah, hvshi i pisah, hvshpi pisah, hvsh i pisah,
I see for thee, of thine, \&c., I see for him, her,

I see for you, I see for them, thou seest for me, of mine, for him, for us, for than,

he sees for me, or of mine, for thee, for him, for us, for you, for them,

we see for thee, of thine, him, ourselves, ourselves, you, them,

you see for me, of mine, him, us, them,
Negative.

ak chị pesoh lih, ak i pesoh lih, akhvchi pesoh lih, aki pesoh lih, chik sa pesoh, chik i pesoh, chik pi pesoh, chik i pesoh, ik sa pesoh, ik chi pesoh, ik i pesoh, ik pi pesoh, hvchik pesoh, ik i pesoh, ke chi pesoh, kil i pesoh, kiloh i pesoh, ke hvchi pesoh, ke hohvchi pesoh, kil i pesoh, hvchik sa pesoh, hvchik i pesoh, hvchik pi pesoh, hvchik i pesoh.

The third plural, is the same as the third singular.

The possessive is sometimes found before the reflexives ille and ill, and sometimes after them; as, im ill anoli, to confess oneself to him; illi nutakvchi, to humble oneself before him; im ille haiakvchi lih, I shew myself to him. 
Combinations with the reciprocal pronouns are formed in the following manners:

chitti pisa lih, itti pisa lih, hvchitti pisa lih, svtti pisah, echitti pisah, hvs sitti pisah,

When two possessives are prefixed to a verb, one is subjective and one objective; as,

vm i nukhąkloh, chim i nukhakkloh, im i nukhąkloh, pim i nukhąkloh, hvpim i nukhąkloh, hvchim i nukhakkloh,
I see for you (or of yours)with you. him, her, them. you, etc.

he sees for me together with me. we see for thee together with thee. you see for me together with me, etc.

thee.
him, her, or them.
us.
us.
you.

The negative is ik sum $\underline{i}, i k$ chim $\underline{i}$, ik im $\underline{i}$, etc.

The following form is a combination of the subjective personal, possessive, and reciprocal possessive:

ish im itti nukhakkloh, you have pity on each other for him. il im itti nukhakloh, we have pity on each other for him. hvsh im itti nukhakkloh, " " "

$\S 22$. Relative pronouns. The article-pronouns supply the place of the relative pronouns, which are not found in Choctaw. This use of the article-pronouns will be seen in the following examples:

Nom. case.

$\begin{array}{llll}\text { Alvm vt, } & \text { Adam he who, } & \text { Alvm a, } & \text { Adam him, whom. } \\ \text { If vt, } & \text { Eve she, who, } & \text { If a, } & \text { Eve her, whom. } \\ \text { lukfi vt, } & \text { clay it, } & \text { lukfi a, } & \text { clay it. } \\ \text { Alvm ak osh, } & \text { Adam, he who, } & \text { Alvm ako, } & \text { Adam, him whom. } \\ \text { If ak osh, } & \text { Eve, she who, } & \text { If ak } 2, & \text { Eve, her whom. }\end{array}$

$\S 23$. Interrogative and responsive pronouns. The interrogative pronouns kvta, nanta, katima, who?, which?, what?, have two forms, one for interrogation, the other for response. They both take the article-pronouns, like the other separable pronouns, to indicate case. Examples:

interrog. kvta hosh ik bi? Who made it? (osh or hosh is the subjective

respons. kvna hosh ik bi tuk. Some one made it. or nominative suffix).

interrog. nanta hosh minti? What is coming?

respons. nana hosh mintih. Something is coming.

interrog. katimak osh achukma? Which of them is good?

respons. kanima kia achukmah. Any one of them is good.

interrog. katimampo hosh ia chi ho? Which (of the two) will go?

respons. kanimampo hosh ia hinlah. Either of them will go.

interrog. katima hosh bvnna? Which of them (all) want it?

respons. kanimik vt bvnnah. Several of them want it. 
Oblique case. kvta ho ish pisa tuk $Q$ ? Whom did you see? nanta ho chibunnah? What do you want? katimak $\mathbf{Q}$ ish chumpa tuk $\mathbf{2}$ ? Which did you buy?

A definite interrogative ends in an aspirate, as, chi bvnnah? Do you want it? A distinctive interrogative ends in a nasal, as, chi bunna? These pronouns may also be subjective, as, nanta hosh yohma wah, nothing could do it; nanta hakosh yohma wa, no one could do it.

$\S 24$. Demonstrative pronouns. These are used to supply the want of a personal pronoun in the third person singular and plural. They are:

ilvppa, this, these, he, she, it, they (near).

yvmma, that, those, he, she, it, they (remote).

Their plural is sometimes formed by adding the word putta, all. They take the article-pronouns, and are declined by it. Examples: Gen. XIV. 20, yvmmak ak, who; Gen. IV. 2, yvmmak okvt, which; Luke XVI. 27, yvmmak oka, him; Luke XVI. 28, yvmmak mvt, they also; 29, yvmmak o, them.

$\S 25$. There are other words used as pronouns, some if not all of which can be also used as verbs and adjectives. They are:

chvfa, one, a certain one, the one, the other.

achofona, any.

achvfaiyuka, each one.

achafoa, some, a few.

aiyuka, each, every.

bika, each, same, both, fellow, Mark IX. 33.

inla, other, another.

inli, self, itself.

itatuklo, both, two together.

luna, many.

kanimona, some, several, from kanimi to amount to, and ona some.

kanimusi, a few.

mih, he, she, it, the same, the identical one, they.

mika, each.

moma, all.

okla, a people, they; used to form the plural of nouns.

okluha, all, the entire crowd, number, or quantity.

puta, all, each and every one; used to form the plural of nouns.

vhleha, all collectively, of persons only.

\section{Declension of the Personal Pronouns.}

1st personal singular.

Nom., I, sia; vno; li.

Oblique, me, s, sa, sv, sai, si; vno.

Possessive, mine, sa, sam, svm, svmi, san; vmmi; vno. 
1st person plural.

Definite form.

Distinctive form.

Nom., we, pia; pishno; e, il.

Oblique, us, pi, p; pishno.

hipia; hvpishno; eho, iloh.

Poss., our, ours, pi, pim, pimi, pin; pimmi. hvpi, hvpim, hvpimi, hvpin; hvpimmi.

2nd person singular.

Nom., thou, chia; chishno.

Oblique, thee, chi, ch; chishno.

Poss., thy, thine, chi, chim, chimi, chin; chimmi.

2nd person plural.

Nom., you, Oblique, you, hvchia; hvchishno. hvch, hvchi; hvchishno.

Possessive, your, yours, hvchi, hvchim, hvchimi, hvchin; hrchimmi.

\section{CHAPTER III.}

\section{VERBS.}

$\S 1$. There are six classes of verbs in Chortaw, the transitive, intransitive, passive, possessive, attributive, and personal.

$\S 2$. The passive verb is made by an internal change of the transitive; but this rarely takes place except in verbs where the transitive effects a visible change in the object acted on. Thus, takchi, to tie; tvllakchi, to be tied; sa tvllakchi, I am bound; but pisa, to see; sa pisa, he sees me, not I am seen. The passive is formed so variously that rules are not attempted. The following examples will illustrate this: hofahli, to abash, passive, hofahya; okpvni, to abuse, pas. okpvlo; atokoli, to aim, pas. atokoa ; atokoli, to appoint, pas. ulhtoka ; okchali, to awake, pas. okcha, siteli, to bind, pas. sita; hopi, to bury, pas. hollohpi; akvlli, to cobble, pas. ulhvta; ikbi, to build, toba, to be built; hukmi, to burn, holukmi, to be burned; chanli, to chop, chaya, to be chopped; bohli, to beat, boa, to be beaten; bvshli, to carve, bvsha, to be carved. Some passives are made by prefixing $\mathrm{lh}$, a locative and intensive particle from vhli, it may be, to the active; as, tohno, to hire, ilhotno, to be hired; ipeta, to feed, ilhpita, to be fed; apoa, to give in marriage, passive, vlhpoba; abeha, to enter a place, passive, vlhbiha.

$\S 3$. The possessive verb is formed by prefixing the inseparable possessive pronouns to other verbs. Thus, ihikiah, he has him standing; imantah, he has him staying; intalaiah, he has it standing (like water in a vessel); imachukmah, he has good, there is good for him; intobah, he has it made; imokpuloh, he has evil, he is evil. 
$\S 4$. The attributive verbs affirm attributes or qualities, and are often used as adjectives and adverbs; as, kullo, to be strong; sa kulloh, I am strong; achukma, to be good; sa achukmah, I am good. The possessive pronouns are affixed to these verbs, as vm achukmah, I have a good one; 2 falaiah, I have a long one, or it is long for me.

$\S 5$. The personal verbs take the objective inseparable pronouns; as, sa lakshah, I perspire; svllih, I die; sanusih, I sleep; saiokchayah, I live; sa hoitah, I vomit. When the act is involuntary, sometimes a change in the form of the verb occurs; as, hoeta lih, I vomit it up; hotilhko lih, I cough; habishko lih, I sneeze; tiopa lih, I breathe.

§6. All verbs end in the infinitive in $i$, a, or o. They all have an affirmative and negative form in all moods and tenses. This is made by means of the negative prefix ik, and by changing the terminal vowel to $o$ when it is $i$ or a; when it is $o$, it undergoes no change. Thus, anta, to stay; ik anto, not to stay; minti, to come; ik minto, not to come; ik ishko, not to drink.

Both forms take the inseparable pronouns as prefixes, and the articlepronouns as suffixes, but both classes of pronouns are written separately, as far as may be. Thus, chi pisa lik vt, thee see I who, I who see thee.

$\S 7$. The modes. There are six modes, the infinitive, indicative, potential, subjunctive, optative, and imperative.

\section{§ 8. The Infinitive Mode.}

This is the root or ground form of the verb, from which the other modes are formed by suffixes. It can be used as a noun, or in an adverbial sense, takchi, to tie, a tier, the act of tying; hvllot takchi, to tie strongly. It takes the inseparable pronouns and the prepositions as prefixes, and the article-pronouns, and particles of tense as suffixes. Examples: chi takchi, to tie thee; chin takchi, to tie for thee; ille takchi, to tie himself; itti takchi, to tie each other; iti takchi, to tie them to each other; a takchi, to tie at; on takchi, to tie on; isht takchi, to tie with; ant takchi, to come and tie; ont takchi, to go and tie; et takchi, to tie hither; pit takchi, to tie thither; takchi a, to tie him to the; takchi ma, to tie simultaneously; takchi ho, to tie distinctive; takchi tuk, takchi tok, to have tied; takcha chị, takcha he, to tie in the future; takcha chin tuk, to be about to have tied; takchi tuk achi, to have been about to tie.

The English infinitive is sometimes translated by the indicative: as Mat. V. 17, okpvni la hi osh aya li tuk keyu; amba aiahlichila he mak a tok, I am not come to destroy but to fulfil; sometimes the English indicative is translated by the infinitive; as Mat. XI. 30, vm ikonla abana ya il abanali ka im vlhpiesa, to put on himself my yoke is easy for him.

The negative form is made by the prefix ik, and the change of the last vowel to o, and corresponds to the English prefixes dis, un, in, etc.; as, iktakcho, not to tie, to untie; haklo, to hear, ikhaklo, not to hear. 
\$9. Modifications of the verb. There are numerous modifications of the ground form or infinitive mode of verbs, each of which forms a new infinitive from which other modifications may arise. Some of the modifications are by internal changes, others by adding a particle. They are:

1. The definite form, takchi, to tie.

2. The distinctive form, takchi, to be tying the while; implying continuance, prominence, and comparison.

3. The intensive form. This is made in various ways:

1. By an increase of emphasis on the accented syllable of a word; as, tókbah, to be so bad; tákchi to tie.

2. By lengthening the vowel sound in the accented syllable; as, chito, to be large, cheto, to be quite large; patvssa, to be flat, patassa, to be quite flat.

3. By inserting a syllable; as, taiyakchi, to tie; chieto, to be decidedly large.

4. By prefixing the diphthong ai to words beginning with a vowel; as, ahli, to be true, aiahli, to be really true; sometimes $i$ is prefixed, as iiksho, to be none indeed.

5. By prefixing a to words beginning with a consonant; as bilia, to be forever, abilia, to be forevermore.

6. By doubling a consonant in the accented syllable; as, alota, to be full; allota, to be brimful; kvnia, to be gone, kvnnia, to be gone off.

7. By inserting a consonant in the final syllable; as, chukva, to go in, chukowa, to go in boldly; ihoa, to call him, i howa.

8. By prefixing ai and inserting another vowel; as, ulhpisa to be right, aiulhpiesa, to be just right.

9. By uniting two verbs; as, ishkottahli, to drink all up; vbitkanchi, to massacre.

4. The frequentative or iterative form; tahakchi, to keep tying.

5. The instantaneous or quick form, by the insertion of $h$ in the accented syllable; as, tahkchi, to tie quickly; vbi, to kill; ahbi, to kill quickly; also the form ahahbi; kvnia, to go away, hvninihya, to vanish.

6. The form for a sudden and single act; as shalvlli, to slide, shalakli, to slip; halvlli, to hold, halakli, to catch hold of.

7. The diminitive form in neuter and attributive verbs; as, chito, to be large, chihto, to be largish; hopaki, to be far off, hopahki, to be rather far off; lakna, to be yellow, lahakna, to be yellowish.

8. The repetitive form, to continue an action in one place and one manner; as, binili, to sit, binininli, to rise up and sit down again; tonoli, to roll, tomononli, to roll back and forth.

9. The causal forms, 1 , by suffixing chi; as, takchichi, to make him tie; ikbichi, to make him do or make, Mat. V. 32; 2, by suffixing chechi; as, ishko, to drink, ishkochechi, to make to drink, to drench; 3 , by suffixing 
chi and prefixing a, locative; as, atakchichi, to tie it to something; 4 , by suffixing li; as, achukmali, to make good; lvshpali, to make hot, to heat. Of these suffixes, chi denotes the causing of the action signified by the primitive verb; as, kvllochi, to harden, from kvllo, to be hard; kolichi, to cause to break, from koli, to break; chechi suffixed to a verb denotes the causing by its own subject of the performance of the action signified by the verb by another subject on an object expressed or understood; as, vno vt vlla ya ikhish a ishkochechi li tuk, I the child him the medicine it did cause him to drink; nafoka ya fohkvchechi lih, I made him put his clothes on himself; chi with a, locative, signifies that two different things are acted upon together, as Mat. XIII. 25, onush ash haiyukpulo yo ant a hokchichi cha, kvnia tok, he came and sowed tares among the wheat, not wheat with wheat but tares with wheat; akakushi yo shuka nipi a aiauvshlichih, she fries (causes to fry) eggs with pork.

The suffix kachi, kechi, kvchi, is added to many verbs slightly altering their sense; as, winali, to shake, winakvchi, to be shaken; basasua, to have stripes, bassasu kvchi, to be striped like a rattlesnake; malvtha, to lighten, malvthakvchi, to flash once; bichota, to bend, bichotakvchi, to bend and spring once.

Note.-Verbs may have all the above forms, but the number of verbs found in all these forms are small.

Active:

Example, takchi, to tie, infinitives.

$\begin{array}{ll}\text { Definite } & \text { takchi, to tie. } \\ \text { Distinctive } & \text { takchi, to be tying. } \\ \text { Intensive } & \text { taiyakchi, to tie firmly. } \\ \text { Frequentative } & \text { tahakchi, to keep tying. } \\ \text { Speedy } & \text { tahkchi, to tie instantly. }\end{array}$

Passive:

$\begin{array}{ll}\text { Definite } & \text { tvllakchi, to be tied: } \\ \text { Distinctive } & \text { tallakchi, to be the one being tied. } \\ \text { Intensive } & \text { talaiyakchi, to be tied fast, or at length. } \\ \text { Frequentative } & \text { talaiyahakchi, to be often tied. } \\ \text { Speedy } & \text { talahkchi, to be instantly tied. }\end{array}$

\section{$\S 10$. Indicative Mode.}

This is formed from the infinitive by prefixing and suffixing the personal pronoums, and suffixing the tense particles for past and future time.

1. Present tense, indefinite, with subjective personal pronouns.

takchih, he, she, or it ties, or they tie, him, her, it, or them.

ish takchih, thou tiest him, her, it, or them.

takchi lih. I tie, etc.

hvsh takchih, ye tie, etc.

e takchih, we tie, etc. (def).

eho takchilh, we tie, etc. (dis). 
2. Pres. tense, definite, with subj. pers. pronouns.

takchishkeh, third sing. and pl.

To this the pronouns are added as in the indefinite.

3. Pres. tense, distinctive, with subj. pers. pronouns.

takchih okeh, third sing. and pl.

To this the pronouns are added as above.

4. Pres. tense, with objective pers. pronouns.

chi takchi lih, I tie thee.

takchi lih, I tie him, her, it, or them.

hvchi takchi lih, I tie you.

5. Pres. tense, with possessive pronouns.

in takchi lih, I tie for him, her, it, them.

chin takchi lih, I tie for thee.

hvchin takchi lih, I tie for you.

in takchih, he ties for him, her, it, them.

chin takchil, " for thee.

an takchih, " for me.

hvchin takchih, " for you.

pin takchih, " for us.

hvpin takchi, " for us.

Past tenses. There are two past tenses, signified by the particles tuk and tok; tuk is used for the immediate and definite past, tok for the remote and indefinite past. They may be combined to form the relative or pluperfect past; as, tuk a tuk, tuk a tok, tok a tuk. The particle a in these expressions is an article-pronoun, and should be rendered thus: he, she, it was.

\section{Past tense definite.}

takchi tuk, he, she, it, they tied, did tie, have tied.

ish takchi tuk, takchi li tuk, hvsh takche tuk,

e takche tuk, eho takche tuk,

$$
\begin{array}{r}
\text { thou } \\
\text { I. } \\
\text { you. } \\
\text { we. } \\
\text { we, etc. }
\end{array}
$$

Past tense distinctive.

This is formed by the article-pronoun, okeh.

takchi tuk okeh, he, etc., tied, did tie, has tied.

Another form of the past tense is made by a nasal sound in the fina vowel, as, takchi, chamo.

\section{Future tense.}

There are two forms of the future, made by the addition of chi for the immediate, and he, or hi, for the remote and indefinite future. The distinctive future is made by suffixing okeh to chị and he; as, chi okeh, hi okeh.

The suffix ashkeh is used for the definite, absolute, or imperative future. 
The past and future are combined to form a relative future; as, tuk a chi, tuk a he, tuk ashke, was to tie; also chin tuk, chin tok, he tuk, hitok, will have, shall have, would have, should have.

\section{§ 11. Potential Mode.}

This is formed from the infinitive by suffixing the articles hinla, may, can, and pulla, must, will.

Present tense (but with reference to future time).

$\begin{array}{lll}\text { Indefinite } & \text { takcha hinlah, } & \text { he, etc., may or can tie. } \\ \text { Definite } & \text { takcha hinlvshhe, } & \text { he, etc., may or can tie. } \\ \text { Distinctive } & \text { takcha hinla hokeh, } & \text { he, etc., may or can tie. } \\ \text { Indefinite } & \text { takchi pullah, } & \text { he, etc., must or will tie. } \\ \text { Definite } & \text { takchi pullvschkeh, } & \text { he, etc., must or will tie. } \\ \text { Distinctive } & \text { takchi pulla hokeh, } & \text { he, etc., must or will tie. }\end{array}$

The past tenses are formed like those in the indicative mode, the tense signs being suffixed to hinla and pulla; as, takchi la hinla tuk, I may or might have tied.

\section{$\S 12$. Subjunctive Mode.}

This is formed from the infinitive by suffixing $\mathrm{km}$ for the definite and okm for the distinctive. The $\mathrm{m}$ takes the definite article-pronoun $\mathbf{a}$ in all its forms.

Note.- km, if, when, whether, is compounded of $\mathrm{k}$, a suffix, definitive of the idea contained in the verb; as, takchik, he ties, at that, in that, or just that; and of $\mathrm{m}$, simultaneous or successive, affirming or supposing something in relation to the idea limited or bounded by $k$, then, when, at the same time or place; takchi $\mathrm{km}$, when he ties then.

This suffix can be added to the other modes in all their tenses; as, infinitive, takchi $\mathrm{kma}$, if to tie him, when to tie him; indicative, takchi $\mathrm{kmah}$, if or when he ties him; potential, takcha hinla kmah, if he can tie him.

\begin{tabular}{ll}
\multicolumn{1}{c}{ Present tense. } \\
takchikmvt, & $\begin{array}{l}\text { definite subjective, } \\
\text { definite objective, }\end{array}$ \\
takchikmah, & if he, etc., tie, then he. \\
takchihokmvt, & distinctive subjective, \\
takchihokmah, distinctive objective, & " "6
\end{tabular}

The past and future tenses are inflected with the personal pronouns as in the indicative, except the forms which end in eh. These are always final, and admit of no suffix nor inflections.

In the past tenses, tuk and tok, the $\mathrm{k}$ in $\mathrm{kmvt}, \mathrm{kmah}$, etc., is dropped, that in the tense particle taking its place. In the remote future, he, the distinctive form is not he okmah, but hokmah. 
The distinctive form okm expresses a condition or supposition with more emphasis, and implies a greater degree of uncertainty than $\mathrm{km}$; as, infinitive, takchi hokma, to tie him, if so; indicative, takchi li hokmah, I tie him, if so it be; takchi la hinla hokmah, I tie him if it can be so.

Examples: Romans XII. 20, chin tvnvp vt hohchvfo hokma; if thine enemy hunger; John XVI. 7, vno vt ia li keyu hokmvno, if I go not away; same verse, amba ia li hokmvto, but if I do go away; Mat. IX. 12, amba abeka yok mak oh chatuk oke, but they (distinctive) who are sick; Luke XVI. 30, im ona hokmvno, if one went unto them, then; Mat. XI. 15, haksobish vt i hinlikmvt, if he have ears, definite; John XIX. 12, ish i hotofi hokmv, if thou lettest him go, distinctive; Phillip II. 1, asha hokma, if there be, a suppositive form; I. Cor. XIII. 8, nan ithana yokmá, whether there be knowledge, a suspensive form.

\section{$\S 13$. Optative Mode.}

This is formed from the infinitive by suffixing $\mathrm{kb}$ definite and okb distinctive. The particle $b$ takes the article-pronoun a in its definite and contradistinctive forms, babato, babano, and distinctive and emphatic as a prefix, in distinctives and contradistinctives.

\begin{tabular}{|c|c|c|}
\hline \multirow{5}{*}{$\begin{array}{l}\text { takchikbat, } \\
\text { takchikbąh, } \\
\text { takchikbato, } \\
\text { takchikbano, } \\
\text { takchihokbat, }\end{array}$} & & $\begin{array}{l}\text { oh ! that he, etc., would tie } \\
\text { it, then he. }\end{array}$ \\
\hline & & it, then he. 6 \\
\hline & subiective & 66 \\
\hline & & 66 \\
\hline & & $\begin{array}{l}\text { oh ! that he, etc., would t } \\
\text { even he, then he. }\end{array}$ \\
\hline takchihok & & \\
\hline & & “" \\
\hline
\end{tabular}

\section{Examples:}

Subjective form: shukbo chumpak bato, oh! that he would buy a blanket (and take it home and wear it, etc).

Objective form: shukbo chumpak bano, oh! that he would buy a blanket, (then others might buy).

Contradistinctive subjective:

shukbo chumpa hokbato, oh ! that he would buy a blanket, (instead of borrowing one), and do something else, wear it, etc.

Contradistinctive objective:

shukbo chumpa hokbano, oh! that he would buy a blanket, then others would come and buy, or do something else.

Luke XIX. 42, nana isht chi ai yukpa he ai ulhpiesa ka ish ithaiyna tokokbato, if thou hadst known, or, oh ! that thou hadst known; even thou, then thou, etc. Iali hokbat, I wish I could go and I (do something); iali hokbah, I wish I could go and he (do something).

The persons, tenses, and numbers correspond with those in the indicative mode. 


\section{$\S$ 14. IMPERAtive Mode.}

Affrmative:

ik takchih, takchih, ak takchih, hvsh takchih,

ho takchi, ohiah,

ke takchi, keho takchi, kiliah, kilohiah, let him, her, it, or them tie. tie thou.

let me tie. ye tie, tie ye (def). ye tie, tie ye (dis). go ye (dis). let us tie (def). let us tie (dis). let us go (def). takchashkeh, let him, her, or them tie.

The particle ashkeh is suffixed to the infinitive in the last word to express an imperative in the shape of a wish.

The imperative negative is formed by changing the terminal vowel of the verb into $o$, and suffixing the particle kia; or particles of negation may be used, such as na, wa, heto, he, keyu.

Examples:

ik takcho kiah, ish takchi nah, ish takcha wah, ish takcha heto, ish takcho he keyu,

do not let him tie. don't you tie him. you will not tie him. you shall not tie him. you shall not tie him.

Double negatives may be used, not, not no; as:

ak tąkcho ki nah;

ak takcho ka wah;

ak tokcha ka he keyuh.

Compare Luke VII. 39, ik akostinincho ka heto, he would not have not known, $i$. e., he would have known.

\section{§ 15. Irregular Verbs.}

The irregular verbs are: vbi, to kill; vmo, to trim, to mow; vla, to arrive; vpa, to eat; ia, to go. The vowel $\mathrm{v}$ in these verbs is dropped in a part of the persons in both numbers; thus:

\section{Affirmative form.}

vpah, he, etc., eats, $i$. e., of one article of food. vbih, he kills.

ishpah, thou eatest. ish bih, thou killest.

vpalih, I eat.

hvshpah, you eat.

epah, we eat (def).

iloh vpah, we eat (dis).

ube lih, I kill.

hvsh bih, you kill. ebih, we kill.

iloh vbih, we kill. 
Negative form.

$\begin{array}{rrrr}\text { ik poh, } & \text { he does not eat. } & & \text { ik boh. } \\ \text { chik poh, } & \text { thou } & & \text { chik boh. } \\ \text { ak poh, } & \text { I } & & \text { ak boh. } \\ \text { hvchik poh, } & \text { you } & \text { livchik boh. } \\ \text { ke poh, } & \text { we } & \text { (def). } & \text { ke boh. } \\ \text { kiloh poh, } & \text { we } & \text { (dis). } & \text { kiloh aboh. }\end{array}$

In the frequentative form of these verbs, the pronouns in the second person singular and plural are modified thus: ahanla, ihishla, sing., ahashlah, pl.

Affirmative form.

$\begin{aligned} \text { iah, } & \text { he goes, } \\ \text { ish iah, } & \text { thou goest, } \\ \text { ialih, } & \text { I go, } \\ \text { hvsh iah, } & \text { you go, } \\ \text { il iah, } & \text { we go, } \\ \text { iloh ia, } & \text { we go, }\end{aligned}$

Negative form. ik aiyuh. chik aiyuh. ak aiyuh. hvchik aiyuh. kil aiyuh. kiloh aiyuh.

iksho, to be none, may be a negative form of vsha or assha.

It is conjugated:

ikshoh,
ikchikshoh,
iksakshoh,

he is not, there is none.

thou art not.

I am not, etc.

and:

ik im ikshoh, he has not, there is none for him, etc.

Keyu, not to be, has no modifications except $\mathrm{h}$ predicative, and the causatives chi and kechi; as, keyuchi, to make it nothing; keyukechi, keyukma, if not, or. Kia, although, is perhaps an imperative form of ia, to go, ikiah, let him or it go. It has no variation except to take $h$ predicative, kiah, although it be.

$\S 16$. It will be seen that verbs have usually but one form for both singular and plural numbers. Some verbs, however, have a plural, made by an internal change; as, hikah, it flies; helih, they fly; binilih, he sits; binohli, they sit; talahlih, he sets it up; talohlih, he sets them up; kopoli, to bite, plural, kobli; kanchi, to sell, plural, kampila; bohli, to lay down, plural, kapulli; tifi, to pluck up. plural, tehli; malleli, to run, plural, yihlepa. Some verbs have this plural form only; as, ilhkolih, they move off; pehlichi, he rules them; chiyah, they sit. Some have the singular number only; as, issoh, he strikes once.

Some few verbs are dual; as, tihlaiah, they two run; ittonachih, they two go there together.

The inseparable pronouns determine the number of the verb in the first and second persons. The third person singular and plural has no personal pronoun; okla is sometimes used as a singular, dual, and plural pronoun; as, anumpulit okla tok, they two spake. 
Note.-By a verb in the plural is meant plurality either in the subject or object; as, wak pelichih, he or they drive cattle, and wak chuffichi, they drive a cow. Here pelichih is in the plural number, and chuffichi in the singular.

\section{CHAPTER IV.}

\section{Prepositions.}

$\S 1$. There are few words in Choctaw that correspond to the English prepositions. The article-pronouns to some extent supply this want. Some verbs involve a preposition in their meaning; as, ona, to go to; vba, to arrive at; bokyupi, to bathe in the creek; husa, to fire at. The inseparable possessive pronouns $\underline{\mathrm{i}}, \mathrm{im}$, in, involve a preposition, to him, for him, of him, from him, against him; so also do the reciprocal possessives, itti, ittim, ittin, to each other, for each other, etc.

The preposition, to, in the infinitive is contained in the simple form of the verb; takchi, to tie. The preposition of, showing the genitive or possessive case is understood; iti hishi, leaf of a tree. When one of the nouns expresses ownership in the other, the inseparable possessive pronoun is used; as, vlla i holisso, the child its book.

§2. As the Choctaw is deficient in single words expressing space and time, it uses in place of them prepositive particles of definite significations. These are:

\section{Locatives.}

They are: a, before consonants; ai, before vowels, and before y. This means the place for, in which, at which, from which, to which, where, there, then; as, afoha, to rest at or in a place, a time for resting; aminti, to come from; ahikia, to stand in; aianta, to stay at or in; ai impa, to eat at or there; ai illi, to die in a (room, etc.), or at (noon, night, etc.); aianuk filli, to think of; aiahni, to long for; ayukfa, to rejoice at.

$\mathrm{Q}$, om, on. This is a more definite locative than a, ai, and may be translated by on or upon; as, onbinili, to sit on; ontalali, to ride on; oyihlepa, to rush upon; ontalali, to set on or upon.

\section{Distinctives:}

Et, anet, here, hither, to this place; et is the simple form, anet the intensive; et is from the verb echi, to reach, hand, or hold this way, to pass in this direction, intensive form anechi. These particles are transitive verbs, and are connected by the letter $t$ with other verbs. Echi has the form of a causative verb, ishtishko a echih, pass the cup hither. Examples: et kanchi, to cast it this way; et anoli, to report hither; et anuk filli, to think this way; awethikia, to stand this way, toward the speaker. 
Pit, thither. This is a subjective directive (made so by the $t$ ). It is from the verb pila, to send off, or throw, from the speaker to some other point. Examples: pit kanchi, to throw that way; pitanoli, to report it thither; pit anukfilli, to think of thither; pit hikia, to stand or lean that way.

3. Instrumental:

Isht, with. This is derived from the verb ishi, to take, with t distinct tive and continuative. Its literal meaning is often lost in the many uses it has as a prefix. Examples: ishtabeka, to be sick with; ishtanowa, to walk with; ishtan umpuli, to talk of ; ishtanuk filli, to think about; ishtholitopa, to take it and be rich.

4. Of motion.

Ant, from ayvt, means motion hither, to a place; as, ant anta, to come and stay.

Ont, from onvt, means motion thither to a place; as, ont anta, to go and stay.

5. Social.

Iba, with, in company with, awaya, to go with, awant, to bring with. Examples: ibatoksvli, to work with; ibapisa, to see with, a school-mate; itanowa, to travel together, a fellow-traveler; awantanta, to stay with; awantia to go with, awaya, to marry, fem. $i$. e., she married him; itawaya, he marries her, or they marry.

6. The war or fire particle:

This is ito, before a consonaut; it, before a vowel. This particle implies mutuality of action between the fire and what is put on it, or between those who kindle fires in a hostile manner against each other. Examples: oti, to kindle a fire; itoti, to fire each other; itotia, to go to war; itotaya, to wage war by fires. It is used in the New Testament, Mat. VII. 50, tvli a bila luak chito ka pit ito-ashacha he, to cast them into the furnace of fire. This particle ito may help us to understand how wars were formerly waged by fire rather than by weapons, these being very imperfect in construction, while fire was always at hand.

§ 3. These particles have various combinations with each other; as, aio, aiom, ai on, ont ai, ant ai, ont isht, ant isht, isht $\varrho$, etc., but as they are written separately, they can be readily understood. Examples: ont ai isht ia, go and of it take and go; isht im ai achukma hokeh, they take and in them have pleasure, it is so; ishtai 2 holissochi, to write on it therewith.

\section{CHAPTER V.}

\section{Nouns.}

$\S 1$. In Choctaw there is no grammatical difference between common and proper, animate and inanimate, concrete and abstract nouns. They have no internal changes nor inflections to denote number, gender, or case. These accidents are supplied by additional words, or are left unexpressed. 
\$2. Number.- Nouns are presumed to be in that number which is most natural to them. If the number is required to be specified, numerals, numeral adjectives, pronouns, or verbs are subjoined. Examples: wak, a cow, cows; wak achofa, one cow; wak tuklo, two cows; wak lawa, many cows; wak moma, all the cows; wak vmmi, my cow or my cows; hatak vt antah, a man stays; hatak vt ashah, men are staying; wak vt tihlaiah, the two cows run.

§3. GENDER.-A few nouns only have names in the masculine and feminine gender; as, hatak, a man; ohoyo, a woman; nakni, a male; tek, a female. When gender is emphatic, these words, nakni, and tek, are subjoined; as, vlla nakni, a boy; vlla tek, a girl; issinakni, a buck; issi tek, a doe.

§ 4. CASE.-All nouns take article-pronouns for specification, emphasis, and case. The subjective relation of a noun to a verb is indicated by the article-pronouns in the nominative case; the objective relation by the article-pronouns in the oblique case. A noun, however, is often used by itself, without the article-pronoun, and may then be either in the nominative or oblique case, the connective alone deciding which, though usually it is oblique. Examples: hatak vt mintih, man he comes; hatak mintiah, man comes, or men come; hatak vt pisah, a man sees, or men see; hatak a pisah, man him (or men them) he sees.

$\$ 5$. The nominative and oblique independent. This occurs when two nouns or pronouns are in a subjective or objective relation to the same verb. In this case the first is emphatic or independent; as, hatak okvto i nitak vt hvshvk ak $\underline{Q}$ chiyuhmi hokeh, man as for, he for him, days they, grass, that which is, like they are, so it is.

hatak achvfa hosh ushi vt in tuklo tok,
man a certain he sons they to him two so it was.

In these sentences, hatak okvto and hatak achvfa hosh, are in the nominative case, and nitak vt and ushi vt, are also in the nominative case. So in the oblique case:

hvchishno ma, isht hvchị,
you indeed,
$\begin{gathered}\text { you, } \\ \text { it shall not be judged to, or you, you shall } \\ \text { not be judged. }\end{gathered}$

$\S 6$. The possessive or genitive sense.

Possession may be shown by simple position; as, iti hishi, tree leaf, the tree's leaf; hatak kvllo, man strength, the man's strength, a man of strength; Chahta okla, the Choctaw nation, miko ibbak, king hand, the king's hand.

Where there is an acquired possession, the inseparable possessive pronouns i, im, in, are inserted between two nouns; as, Chan in chuka, John his house. It is probable that the method of indicating possession by position arose from an elision of this pronoun, as this method is most frequent in names of the human body and its members, of near relatives, in nominative and oblique independent nouns, and generally in such as are obviously integral parts of each other, or by nature closely connected. 
Examples: miko ibbak, the king (his). hand; miko ushe, the king (his) son; iti vni, a tree (its) fruit; iti hakshup, a tree, its bark; wak pishukchi, a cow (her) milk.

Names of time take the possessive pronoun; as, $\underline{i}$ nitak, his day or days, which might also be regarded as $\underline{i}$ dative, to him, for him, as in wak $\underline{\mathbf{i}}$ kanchi, he sells a cow to him or for him.

$\S 7$. The objective (accusative and ablative) sense.

This is made by article-pronouns subjoined to nouns; as, hatak a, man him, man whom, man that. In forming the ablative of time, place, cause, the verb, not the noun, takes the preposition; as, hatak vt a hikiah, the man stands in a place; isht ikbih, he makes it with. The vocative can be indicated by the particle mah; as, miko mah, 0 king. ${ }^{1}$

§. Classes of nouns.

The nouns are either primitive or derived. The former cannot be traced to any root; such are, oka, water; tvli, a stone; hatak, a man; ibbak, the hand; the latter are derived from verbs, adjectives, other nouns, etc.

§ 9. Derived nouns.

The following examples will show the derivation of nouns:

From transitive verbs:

chanli, to chop, chanli, a chopper, the act of chopping.

bvshli, to saw, a sawyer, the act of sawing.

From intransitive verbs:

nowa, to walk, a walk, the act of walking.

pisa, to see, a seer, a sight.

From passive verbs:

talakchi, to be bound, a bundle.

holitopa, to be honored, honor.

kvnia, to be lost, the loss, the act of losing.

From neuter verbs:

kvllo, to be strong, strength.

ahli, to be true, truth.

From verbs with the locative particle a or ai:

achanli, a chopping place.

impa, to eat, aiimpa, a table.

apisa, a looking glass.

abvsha, a saw-pit, from bvsha, to be sawn.

\footnotetext{
1 In one portion of his manuscript Mr. Byington propounds the following query; "Cannot all Choctaw nouns be treated as verbs? The root may be considered as in the infinitive mood; as, hatak, to be a man; hatak', it is a man; hatak okmvt, if a man." Prof. H. Steinthal, on the contrary, thinks that the peculiar formation of American tongues makes nouns, but no real verbs. $\mathrm{He}$ says of the Aztec: "das Mexikanische in seinem Ansatze zur Wortbildung Nomina gebildet hat, aber keine wahrhaften Verba" (Charalteristik des Sprachbaues, s. 218). The author of Eiudes philologiques sur quelques Langues Sauvages de l' Amerique, p. 38, says: "Les noms algonquins ne se déclinent point, ils se conjuguent." Prof. Steinthal, however, is right. The primitive expressions in these languages are concrete, not abstract, - nouns, therefore, not verbs.
} 
From verbs with the particle isht instrumental:

isht bvsha, a saw.

isht talakchi, a band.

From verbs with the particle na or nanta:

nakanchi, a seller, from kanchi, to sell.

nanithana, a pupil, from ithana, to learn.

From verbs with the definitive particle ka or kakah:

falamaka, the return, from falama, to return.

chukbika, a corner, from chukbi, to be a corner.

lapalika, the side, from lapali, to be the side of.

chitokaka, the Great One, God, from chito, to be great.

From the verb ahpi, to be first in time:

achąfahpi, the first one.

ishahpi, the first taken.

tofahpi, to first of summer, the spring.

hushtolahpi, the first of winter, the autumn.

vttahpi, the first-born.

With ushi, a son, to make a diminutive:

bokushi, a brook, lit., son of a creek.

hinushi, a path, from hina, a road.

ibbakushi, the fingers, from ibbak, the hand.

iyushi, the toes, from iyi, the foot.

With vpi, a stalk, stem, trunk of a tree, main channel of a river, etc:

iyvpi, the leg.

bissvpi, a briar, bramble.

hatakvpi humma, a red man, an Indian.

From the union of two nouns:

bila pvla, lamp-oil.

hvpi oka, brine, salt water.

iti hishi, leaf, leaves.

nishkin okchi, tears.

From the union of three nouns:

chukfi hishi shapo, a wool hat, sheep-hair-hat.

wak hakshup shukcha, a saddle-bag, cow-skin-bag.

From a noun and an adjective:

bota tohbi, flour, white-flour.

hvpi champvlli, sugar, salt-sweet.

From two nouns and an adjective:

issuba haksobish falaia, a mule, horse-ears-long.

From a noun and a verb:

iti bvshli, a tree-sawyer.

shapo ikbi, a hat-maker.

shulush ikbi, a shoemaker. 
From two words connected by an article-pronoun:

kanchit aya, a peddler, one that sells and goes.

mvllit kvnia, a runaway, one that runs and is gone.

From two nouns and a verb:

bila pvla ikbi, a lamp maker.

lukfi ampo ikbi, a potter. ${ }^{1}$

Other combinations are also in use.

10. Abstract nouns.

These are usually formed from neuter verbs; as, kvllo, to be strong, strength; achukma, to be good, goodness; ahli (distinctive form of vhli, edge, end, point, limit), to be true, truth.

The translators of the New Testament rarely, however, use these words alone, but combine others with them.

For example:

nayimmi, faith, I. Cor. XIII. 13.

nannihullo, love.

nanisht i hullo, love.

nanithana, knowledge, 2 Pet. $1,5$.

ishtaivlbi, redemption.

isht aholitopa, glory, Mat. VI. 13.

Often circumlocutions are used; as,

nan-isht hvsh il a nanaiya, your peace, lit., the thing by which you have peace in yourselves, Luke X. 6 .

The suffix nana or nan gives an intensive signification; as, nanihullochi, accursed thing, Joshua VII. 13.

$\S 11$. Proper nouns, and terms of relationship.

These take the article-pronouns, and are construed like common nouns. Some proper nouns are simple, others compound. Chahta, Mvskoki, Chalaki, Wishashi, Shawvno, are simple, uncompounded names. Bulbaucha, the Choctaw name of New Orleans, is compounded of bvlbaha assha, where there is bvlbaha, unintelligible talking in different languages, as in Babel of old.

$\begin{array}{lll}\text { Apalachicola, } & \text { apelvchi okla, } & \text { helping people, allies. } \\ \text { Pensacola, } & \text { pashokla, } & \text { hairy people. } \\ \text { Pascagoula, } & \text { pvskokla, } & \text { bread people. } \\ \text { Tombigbee, } & \text { itomikbi, } & \text { box makers. } \\ \text { Bok humma, } & & \text { Red river. }\end{array}$

Boktuklo, river two, applied to a creek the channel of which is divided by an island.

The terms of relationship are numerous, and differ materially in application from those used in the English tongue; as will be seen in the following list:

\footnotetext{
1 A number of words have been adopted from the English, and a few from French and Spanish. They all suffer some change. Thus, katus, a cat; shapo, chapeau; wak, vaca (Sp.); enchil, angel.
} 


\section{Kinship by blood.}

1. In the male line.

vmafo, my grandfather, the father of my father or of my mother, their fathers, brothers, and male cousins.

aki, my father, his brothers, his male cousins, his uncles and nephews, their brothers and male cousins.

vmoshi, my maternal uncle, his brothers and male cousius.

$a k n i$, the eldest among brothers, and male cousins.

ushi, a son, svso, my son, son of the father, father's brothers, male cousins, son of the mother, her sisters and female cousins, son of the father's sister (said by this father's son).

sabaiyi, my nephew, a son of my sister or her female cousin.

sapok nakni, my male grandchild, my sister's male grandchildren, my brother's children (said by an aunt).

ittibapishi, brother, literally those who suck together, a general name for brothers and male cousins.

vmmvnni, my elder brother or cousin.

sa nak fish, my younger brother or cousin.

i $n a k f i$, her brother, spoken by a woman.

2. In the female line.

vppokni, my grandmother, her sisters, female cousins and their mothers. hvshke, my mother, her sisters, and female cousins.

ahukni, my aunt, her sisters and female cousins.

$a k n i$, the eldest child among sisters and female cousins.

vshetik, or svsotek, my daughter, the daughter of my sisters or female cousins, the child of my father's sister, her sister or her cousin.

sapoltek, my granddaughter, my sister's grandchildren, the female child of a brother's sister.

itte bapishi, sisters, female cousins, common gender.

vmmvnni, my eldest sister or cousin.

sanak fish, my younger sister or cousin.

antek, my sister or female cousin, said by a man.

\section{Kinship by marriage.}

hatak, husband, literally, her man.

tekchi, wife, im ohoyo, his woman.

svppochi, my father-in-law, said by the man.

svppochi, ohoyo, my mother-in-law, said by the man.

vmvfa, my father-in-law, said by the woman.

vppokni, my mother-in-law, said by the woman.

sayup, my son-in-law.

sapok, my daughter-in-law.

vmalakusi, my brother-in-law, brother of my wife.

vmalak, my brother-in-law, husband of my sister.

vmafo, my uncle, the husband of my aunt.

vmalakusi ohoyo, my sister-in-law, sister of my wife.

sahaiya, my sister-in-law, wife of my brother, also wife of my uncle, or of my nephew. 
uppo, my sister-in-law.

sapok, my sister-in-law.

vshke, the wife of my father's brother.

haloka, a family name for son-in-law, father-in-law, and mother-in law.

While formerly the kinsmen (iksa) and the peoples (okla) had specific names, the family had none. ${ }^{1}$. The names of individuals were significant of some trait or quality. Some of the masculine names mean Come and kill, Stand and kill, Kill all, Kill and go; some of the feminine names signify Giver, Bringer, She who loops up her hair, Take water and give him. In times of war brave men received titles, such as Red bird, Red knife, Red owl, etc.

The individual name is sacred, and is never used in common conversation; the name of relationship, my brother, my cousin, is used instead. The wife speaks of her husband as vlla $\underline{\mathrm{i}} k i$, the children's father.

The ancient law of marriage was that no man could choose a wife in his own $i k s a$. Hence the matter of clan relationship became one of great importance, and upon it the terms of relationship in general were based. In common salutations, the husband addressed his wife's clan as vm okla mah, my people, but his own clan as vm ai okla mah, inserting the locative particle ai, with an emphatic sense.

Parents usually refer to their offspring as vlla, the child, or children.

There are no words, such as great-grand-father, great-grand-son, etc., to express relationship in the same line beyond grandfather and grandson. All ancestors and descendants more remote than these are called indiscriminately by these terms.

$\S 12$. Termination of nouns.

Nouns may end with the vowels a, i, o, $\mathrm{u}$, and with the consonants $\mathrm{f}, \mathrm{h}$, $\mathrm{k}, \mathrm{l}, \mathrm{n}, \mathrm{p}, \mathrm{s}$, and sh; fakit, a turkey, the only noun ending in $\mathrm{t}$, is probably a borrowed word. Those which end with a consonant take the articlepronouns which begin with a vowel sound; as, at, vt, osh, ot, ocha, a, 2 , ona, or with the euphonic y; as, yvt, yosh, yocha, ya.

\section{CHAPTER VI.}

\section{Adjectives.}

$\S 1$. The words used as adjectives, or attributes of nouns, are in reality verbs. All the classes of verbs are used to modify nouns, but the attributive neuter verb is that most frequently employed. When subjoined to nouns as adjectives, the verbs drop the inseparable and article-pronouns which belong to verbs alone. but continue to be modified by the internal changes of the verb.

\footnotetext{
1 The Choctaws were formally devided into two iksa, and three "fires" or districts. The latter were: okla falaia, the long people; ahepvt okla, potatoe-eating people; okla hannali, six peoples. The iksa lived promiscuously throughout the nation and their establishment was attributed to sacred authority. This information I owe to Col. P. P. Pitchlynn, a thorough native Choctaw scholar, who has kindly read the proof of Mr. Byington's Grammar with me.
} 
$\S 2$. The adjective follows the noun it qualifies, and the article-pronouns subjoined to nouns are removed and placed after the adjective. Thus, hatak vt mintih, a man is coming; hatak achukma yvt mintih, a good man is coming. The adjective agrees with its noun in number and case.

§ 3. Affirmative and negative forms.

Adjectives are changed from the affirmative to the negative forms as verbs are. Thus, hatak kvllo, a strong man; hatak ikhvllo, a man not strong; ahli, true; ikahlo, not true. A noun with its adjective may be conjugated like a verb through the modes and tenses in the affirmative and negative forms.

§4. Number.

Adjectives have a singular and plural number. The plural is formed from the singular by internal changes, and by the addition of other words. Examples:

\begin{tabular}{|c|c|c|}
\hline Singular. & & Plural. \\
\hline achukma, & good, & hochukma. \\
\hline chito, & large, & hochito. \\
\hline falaia, & long, & hofaloha. \\
\hline falvsa, & long and slender, & falvspoa. \\
\hline pvtha, & wide, & hopvtka. \\
\hline ibakchufanli, & tapering, & ibakchufashli. \\
\hline ibakhatanli, & bald faced, & $\begin{array}{l}\text { ibakhatashli. } \\
\text { ibaknashashli. }\end{array}$ \\
\hline $\begin{array}{l}\text { ibakpishanli, } \\
\text { ibaktasanli, }\end{array}$ & $\begin{array}{l}\text { round and pointed, } \\
\text { starved in the face, }\end{array}$ & $\begin{array}{l}\text { ibakpashashli. } \\
\text { ibaktasashli. }\end{array}$ \\
\hline yushkotoli, & short, & yushkotushli. \\
\hline yushbonoli, & curly haired, & yushbonushli. \\
\hline yushtololi, & short, & yushtolushli. \\
\hline okchvmali, & green, & okchvmashli. \\
\hline
\end{tabular}

$\S 5$. Comparison.

The degrees of comparison are much more numerous than in English. They are expressed either by internal changes, or by the addition of othe: words. Example: achukma, good.

Descending graduation.

achukma ik ono, achukma ik lawo, achukma momaka ik lawo, achukma iklawokit taha, Positive degrees. achukma, good. achokma, goodish. achuhkma, achoyukma, achukma, achohukma, not good enough.

less good.

less good than all.

completely less good than all.

\section{good emphatically.}

good in an increased degree.

good distinctly compared with others.

good and growing better. 
Comparative degree.

achukma i shahli, better.

Superlative degree.

achukma moma i shahli, achukma kvt i shaht tahli,

best.

achukma kvt i shaht taha,

best, he completes it, subjective. best, it is completed, objective.

The last two expressions are attempts to translate the English superlative, and are not natural to the language. They are rarely heard.

Diminutives.

$\begin{array}{llll}\text { iskitini, } & \text { small, } & \text { iskitvnisi, } & \text { smallish. } \\ \text { okpulo, } & \text { bad, } & \text { okpulosi, } & \text { baddish. } \\ \text { kanomi, } & \text { few, } & \text { kanomusi, } & \text { fewish. }\end{array}$

Sometimes it is expressed by a kind of lisp; as for ikchito, not large, say iksito.

§. Numerals.

These are all parsed like verbs, but are here called adjectives, in accordance with custom.

Cardinal.

1. achvfa.

2. tuklo.

3. tukchina.

4. ushta.

5. tahlapi.

6. hannali.

7. untuklo.

8. untuchina.

9. chakali.

19. pokoli.

11. auahchvfa.

12. auahtuklo.

13. auahtuchina.

14. auahushta.

15. auahtahlapi.

16. auahhannali.

17. auahuntuklo.

18. auahuntuchina.

19. auah chakali.

20. pokoli tuklo.

30. pokoli tuchina.

100. tahlepa achvfa.

1000. tahlepa sipokni.

The word auah means with, akucha, out of, over. There are no words for portions less than one half.
Ordinal.

tikba.

atukla, or hittukla.

atuchina, or hittuchina.

aiushta, or isht aiushta.

ishttahlapi.

isht hannali.

isht untulo.

isht untuchina.

isht chakali.

isht pokoli. 


\section{CHAPTER VII.}

Adverbs.

$\S 1$. Adverbs in Choctaw are verbs as well as adverbs They are either primitive or derived. The former are single words, such as beka, always; bano, only; illa, merely; tokba, very much; aूhli, certainly; pulla, surely.

$\S 2$. Derived adverbs are formed in various ways. When two verbs have a connective between them, the first of them may serve merely to qualify the second and must then be rendered adverbially, though both may be parsed as verbs; as, achukmalit hvsh hoyashke, do ye search diligently, Mat. II. 8.

Adverbs of place are formed from the demonstrative pronouns ilvppa, here; yvmma, there. These take some of the article-pronouns; ilvppakinli, right here; yvmmakinli, right there.

Adverbs of number are derived from the numerals; as, ushta ha, four times; ai ushtaha, at the fourth time.

Adverbs of time past are derived from the definite article-pronoun ash, renewed mention; as, mish ash, day before yesterday; hopakik ash, long since, long ago.

Adverbs modify each other; fehna chohmi, somewhat very; fehna pulla, surely very. The degree of modification is varied after the manner of adjectives, by emphasis, by prolonging the sound of a word, or by inserting a syllable; as, fehna, fiena; cheki, chehki; chiki, chehika.

Diminutives are formed by adding si; as, olatomasi from olatoma, this way, on this side of; bilikasi from bilika, close by.

§ 3. Interrogatives. These are definite and distinctive. The distinctive calls for a definite answer; katima ish ia hoh cho? where are you going? anchuka ia lih, I am going to my house.

In speaking an interrogative tone is used, and to increase the strength of the interrogation the final syllable ends with a nasal sound; anta? is he staying? minti ? is he coming? As there is no predicate in such interrogations, the verbal $\mathrm{h}$ final is dropped. There is a milder interrogative where the nasal sound is dropped, and the $h$ predicative is suffixed; as, yohmik ah? is it thus? yobatuh ah? could it be? Interrogatives with the nasal are distinctive; without the nasal they are definite.

An interrogative in the negative demands an affirmative reply; as, yvmmak keyu? is it not that?=it is that.

The principal interrogative adverbs are katima? or mvto? where? nanta? what? katiohmi? how? cho? an interrogative particle. Examples:

Katima ishia hạ? Where did you go? (definite.)

Katima ishia ho? Where did you go? (distinctive.)

$\S 4$. Adverbs take the article-pronouns, and some inseparable pronouns; as, sa tikba, before me (in place); an tikba, before me (in time). When they follow verbs, the article-pronouns of the verbs are removed, and placed after the adverbs. 


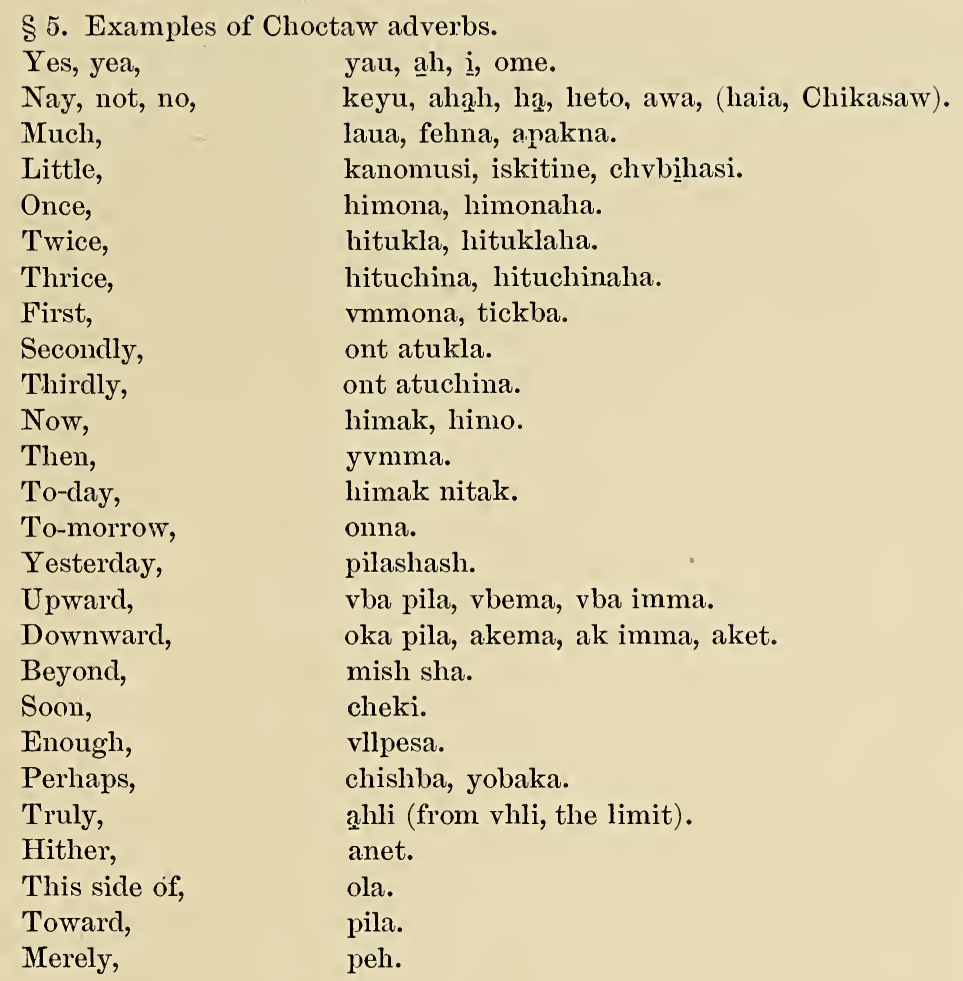

\section{CHAPTER VIII.}

\section{Conjunctions.}

$\S 1$. Conjunctions connect words, sentences, clauses and paragraphs, and commence and close sentences. They are definite and distinctive.

Definite conjunctions usually end with $t$, vt, or a ; as, mihmvt, mihma, and. The distinctives end with osh or 2 ; as, mihi osh, mihin. Some are both definite and distinctive; as, okvt, oka, where ok, a demonstrative distinctive, is combined with vt and a definite.

$\S 2$. They take some of the article-pronouns to exhibit the nominative and oblique cases; as, mihmvt, nom. case, and he, mihma, oblique case, and him ; mih is used as a personal pronoun in the third person singular. Mihmvt is literally "he then he ;" mihma, "he then him ;" mihmvt contains the verb of existence (h predicative) and the subjective copula; mihma likewise contains the verb of existence, and solves the subjective 
copula, and thus it acts on the subject-the subjective copula being solved, a new subject with its copula takes its place. This conjunction may be translated by any of the personal pronouns in the third person.

$\S 3$. The conjunction in the nominative case connects two or more subjects to one verb; as, Acts II. 8-11, where mikmvt and micha connect the names of several nations with eho haiyak loshke.

When there is one subject and two or more predicates, the subject is connected with all the predicates; as, Luke XV. 13, where the connective is suffixed to the predicates as a copula.

But when another subject and predicate following the first are connected with it, the conjunction is in the oblique case. This change of case gives notice of the succeeding subject and predicate; as, Mat. I. 2: Eblaham vt Aisak a tobachi tok; atuk@ Aisak vt Chekob a tobachi tok; here, atukg is in the oblique case, and connects the two prepositions, and shows two different subjects. If it were atuk osh instead of atuko it would make Abraham a subject of the second preposition. The genealogy of the Saviour in Luke III., illustrates the same usage. The conjunction mihma is there used, "and he," the subject of the next verb. This change in the conjunction does not change the subject to the object. It gives notice of another subject, and connects them both by mihma. The copula is solved, and the way opened for another subject to take it. Thus, in Luke XVII. 10: achvfa kok osh Falisi okma, achvfa kvto publikan a tok; okma is in the oblique case. These instances exhibit the difference between a conjunction in the nominative and oblique cases.

$\S 4$. Conjunctions are divided into the following classes:

1. Copulatives; definite subjective, and, then, $t$, cha, micha, mihmvt, mikmvt, yohmi cha, yumohmi cha, yohmi mvt, yumohmi mvt.

definite objective, na, mina, mihma, mikma. distinetive, mih ho, mih hosh.

2. Distinctives ; or, if not, unless, except, but, keyukmvt, keyu hokmvt, amba, ikshokmvt, keyukma.

3. Concessives; although, nevertheless, be it so, admit it. They concede something which has been said. They are kia and amba. The distinctive article-promouns osh, o, and oh, often precede kia, as akohkia, okako kia.

4. Adversatives; but, yet, notwithstanding, amba, kia; atuk ak $\varrho$, but, Luke XIX. 14.

5. Causals ; therefore, for, because, as, so as, okvt, yohmi hosh, yohmi kokvt, yomohmi hosh, yomohmih hoh, yomohmi hokah.

6. Illatives ; therefore, wherefore, on account of, yomohmi hokvt, yomohmi hokah.

7. Finals ; because, for, hokvt, hokah, yohmi hokvt, yohmi hokah.

8. Conditionals ; if, lest, when, then, provided, kmvt, kma (def.), okmvt, okma, (dis). 
9. Suspensives ; whether, whether or, kmá (def.), okmá, (dis.), ish tolbichikmá; ish lusachikmá, whether white or black, Mat. V. 36.

Examples of conjunctions:

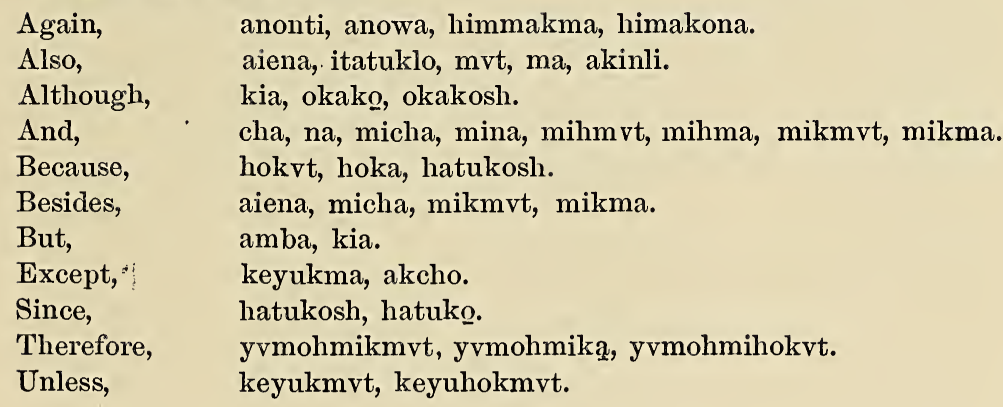

\section{CHAPTER IX.}

\section{INTERJECTIONS.}

$\S 1$. The Interjections may be divided into two classes, the subjective and the objective.

$\S 2$. The subjective interjections.

These are produced by a sudden ebullition of feeling and merely manifest the state of the speaker's mind, as akshukeh! oh! on account of pain from water or cold; akshupeh ! oh ! when the pain is from fire; ulleh ! for any severe pain; ikikelı! when in distress of mind or body.

$\S 3$. The objective interjections.

These are employed to excite the attention of the party addressed; intah !, ok !, okintah !, well! now! used for defiance or banter; yak eh ! look here!, yak okeh, thanks to you ; yokokeh, in lamentation ; omeh ! omishkeh ! to call attention, Give ear! There are interjections for times of sport, of mourning, of war, victory and defeat. Some are common to both sexes, some used by only one.

$\$ 4$. Interjections chiefly used by men.
Ahąh,
no! stop ! take heed!
Pullashkeh, God forbid !
Auohmeh,
ah indeed!
Hahah, oh!
Han, oh! what!
Humpheh, oh ! in anger, defiance, or pain.
$\mathrm{Ok}$, well ! now! as, I dare you ! 
Okintah, well, come on, I dare you.

Omeh, to invite the attention of hearers.

Omishkeh, the same in more solemn style.

Yakoh! yakih!, a shout by the warner to the ball-players.

Interjections chiefly used by women.

Aiena,

Aiyenaheh,

alas, wo is me.

Ehwah,

Aiheh,

alas, wo, uttered at funerals.

Wehkah,

fie! begone, in reproach or disgust.

oho! half in fun and half in earnest.

Kaihoh,

quit! don't !

oh! in fear.

Interjections common to both sexes.

Ok hoh,

Akshukeh,

Okshupeh,

Ehah,

Hai,

Hok,

no! no ! quit ! in anger.

oh dear! it hurts me!

oh! it burns!

woe, woe!

in disappointment.

oh!

Hush,

alas!

Hushha,

Ikkikeh,

Intah,

Issah,

Mah,

Makhalokah,

Mishia,

Okkvnno,

Okokkoh,

alas!

alas! pity!

well, now, come, enough !

quit! be off ! stop !

look there now, sign of vocative.

"let it be so to him," in contempt.

begone !

indeed!

oh dear! alas ! 


